\title{
A NEW SET OF POLYPTYCH DOORS FROM FOURTEENTH-CENTURY CASTILE
}

\author{
Maeve O'Donnell \\ modonell@getty.edu \\ https://orcid.org/o000-000I-5105-1578
}

Recepción: 13-08-2018 / Aceptación: 29-09-2018

\section{Resumen}

El enfoque académico en los retablos y frontales de la Castilla medieval no ha avanzado mucho debido a los pocos ejemplos de estos muebles que sobreviven de este reino ibérico. Este estudio establecerá los primeros pasos para remediar este desequilibrio al proporcionar una visión general del cuerpo de retablos y frontales supervivientes de la Castilla medieval y al prestar especial atención a un conjunto de paneles recién descubiertos que ahora se encuentran en una colección privada. Estos paneles una vez comprendieron un políptico que se podía cerrar y mostraban imágenes de la vida de la Virgen, además de una imagen solitaria de Santa Catalina. Es en referencia a este último que el trabajo aquí se conoce como las Tablas o el Políptico de Santa Catalina. El formato y el programa iconográfico de las tablas comparten muchas similitudes sorprendentes con otros paneles supervivientes. Y, sin embargo, las diferencias sutiles entre las representaciones de figuras, el modelado de túnicas y las composiciones de escenas sugieren que fue creado por uno de varios artistas que trabajan en la región. Como parte de este grupo, el Políptico de Santa Catalina presenta una importante evidencia material que nos ayuda a comprender mejor la producción de retablos y frontales en la Castilla del siglo XIv. Las tablas también ayudan a establecer aún más la importancia de Castilla en las discusiones actuales sobre el desarrollo y la función de los retablos en toda la Europa medieval.

\section{Palabras clave}

Retablos, Frontales, Polípticos. Castilla, Talla en madera, Culto a los santos, Santa Catalina, Altares, Talleres 


\begin{abstract}
Scholarly focus on altarpieces and frontals from medieval Castile has long struggled to advance due to the fact that few examples of these altar furnishings survive from this Iberian kingdom. This study will lay out the first steps for remedying this imbalance by providing an overview of the surviving corpus of altarpieces and frontals from medieval Castile and by drawing particular attention to a newly discovered set of panels now held in a private collection. These panels once comprised a closable polypytch and display images from the life of the Virgin. It is in reference to a solitary image of Saint Catherine that the work is here known as the Panels or Polypych of Saint Catherine. The format and iconographic programme of the panels share many striking similarities with other surviving panels. And yet, subtle differences between the representations of figures, modelling of robes and compositions of scenes suggest that it was made by one of many artists working in the region. As part of this group, the Saint Catherine Polyptych introduces important material evidence that helps us to better understand the production of altarpieces and frontals in fourteenth-century Castile. The panels also help to further establish the importance of Castile in current discussions over the development and function of altarpieces across medieval Europe.
\end{abstract}

\title{
Keywords
}

Altarpieces, frontals, polyptychs, Castile, wood carving, cult of saints, Saint Catherine, altars, workshop practices.

Like elsewhere in medieval Europe, many Castilian altars were furnished with altarpieces and frontals of varying shapes and sizes and with significance to members of their corresponding communities. Surviving altarpieces and frontals from Castile - of which there are far more than have been previously noted by scholars - reveal the contribution of local artists and craftsmen to the embellishment of the altar in this kingdom. Scholarship on medieval Castilian altar furnishings has largely focused on dating individual altarpieces, overlooking larger questions of patronage and manufacture. The surviving corpus of altarpieces and frontals offers a window into an important and hitherto largely neglected tradition of the production of altar furnishings in Castile.

A recently discovered set of polyptych doors in a private collection provides a unique and invaluable addition to the corpus of Castilian fourteenth-century wood-carved altarpieces and frontals (Fig. I). Its figures and decorative elements show both reliance on models and creative adaption of those models to specifica- 
tions likely set out by the patron. Evidence for this relationship between makers and patrons contributes, in turn, to a richer and more nuanced understanding of the production of altarpieces and frontals in northern Castile in the medieval period; a topic of investigation that has seen little progress over the last half century. Contrary to the belief that Castile lacked a tradition of altarpiece production in the medieval period, these panels substantially augment the body evidence of a large network of artists and workshops active in northern Castile during the fourteenth century.

Through an analysis of these new panels, this article will therefore present evidence showing that medieval Castile enjoyed a rich tradition of altarpiece and frontal production; that the production of these panels demonstrate the involvement of patrons; and that the resulting works could include a wide range of iconographic programmes, including scenes from the lives of the Virgin, Christ, the saints and from different passages of the Bible. Information drawn from the other panels of the corpus will, in turn, shed further light on the practice of commissioning, designing and assembling such works. The closing sections of this study will provide a summary of the study of Castilian altarpieces and frontals to date. It will be shown that such investigations have been negatively impacted both by the survival of so few examples - a scenario that has recently changed and by an long-standing acceptance of the hypothesis that altarpieces developed in response to decrees set forth as a result of the Fourth Lateran Council in I2I5. Studies of the function and development of altarpieces and frontals outside of Spain have recently benefited from challenges to this position, resulting in the proposal of alternative hypotheses that stress the importance of patrons and of the veneration of local saints. The corpus of panels at the centre of this study - and the Saint Catherine Panels in particular - introduce valuable material evidence in support of these new perspectives, finally securing a place for Castile in discussions of altar furnishings in medieval Europe.

\section{THE SAINT CATHERINE PANELS}

A polyptych acquired in 2017 by a private collector comprises a set of doors, each made up of two slender panels. The upper and central rows contain scenes from the life of the Virgin and Infancy of Christ. Amongst the figures of the lowest register, a small representation of Saint Catherine stands out, her face turned directly to the viewer. In reference to this representation of the female saint - a figure that does not appear on any other surviving carved panel or fragment - the 
panels will forthwith be referred to as the Saint Catherine Polyptych (Fig. 2). Little is known about the provenance of the Saint Catherine panels. According to a report leading up to the panels' sale and written by Dr Luca Mor, they were acquired from a private collection in New York City, though little additional information is provided (Mor, 20I6, unpaginated). A technical investigation, also conducted before its sale, concluded that the work had undergone at least one previous conservation campaign in which holes produced by woodworms on the interior and exterior faces had been filled (Mor, 2016, unpaginated). Digital radiographs were also able to show the use of metal dowels and nails for attaching frames and groups of figures to the supporting panels (Radelet, 2016, p. 8). Underpainting on some of the faces of the figures is also visible through examination, and is important in recapturing some details that have been lost under post-medieval polychromy.

In general, however, the work survives in sufficiently good condition for viewers today to appreciate the compositions, figures and ornamental details that comprise the four panels. Carved separately from their supports, groups of figures appear to have been carefully set into small niches made-up of architectonic details. In the uppermost scene of the far-left panel, for instance, the kneeling Saint Elizabeth is accompanied by a small tree or bush behind her head which fills in the space beneath the arch of the frame almost exactly (Fig. 3). The line of sight of her cousin, Mary, on the other hand, is at the level of the cusp of that arch, giving the impression that she sees over Elizabeth towards the other scenes in the adjacent gables, which include the Nativity, the Annunciation to the Shepherds and the Flight of the Holy Family into Egypt. Indeed, Mary's erect position in the Visitation niche is not repeated by any other figure across this row of scenes until the figure of Saint Joseph carrying Christ on his shoulders at the opposite end (Fig. 4). Both these figures, like Mary, look outwards rather than back into their corresponding composition. When the doors were closed, Mary and her family would be standing next to one another, facing the narratives that depict key moments in their lives.

The heads of most of the other figures across the four panels are either in profile or face one another. For instance, two niches containing depictions of King Herod directing soldiers and speaking to the three Magi clearly show the monarch engaged with the surrounding scene (Fig. 5). In the Massacre of the Innocents composition, Herod looms over the soldiers, his face cocked to one side and his hand raised to his chin as if in thought. The smaller soldiers next to him turn in his direction, anticipating the command to kill their infant captives. In the following meeting with the Magi, Herod has decreased in stature and has 
turned his head inwards slightly as he addresses his royal visitors, allowing the viewer to see a small canine-like devil whispering into his ear.

The figures of the lowest register do not appear to make-up narrative scenes (Fig. I). The tallest figure on the far left is crowned and carries a vessel. His thick beard and long locks resemble those of the tallest Magus in the scene of Herod addressing the Magi in the row above. Consequently, this large figure may be yet another representation of an eastern king. The figures of the next two niches appear to be a crowned Saint Catherine with her broken wheel and Saint Joseph leaning on his staff, as he does in the Nativity scene in the gable above. Facing outwards, the figure of Saint Catherine stands out amongst the characters in the narratives above who interact with one another (Fig. 2). Her frontal position also contrasts with the bowing Saint Joseph in the following niche. Indeed, the posture of the large Magus and Saint Joseph present them as devotees of the female saint, possibly alluding to her importance to devotees in the corresponding community. In the bottom three niches of the right set of doors, there appear two more crowned Magi, also resembling those in the central row of the left panel, and a tall female figure holding a book. While her posture recalls scenes of the Annunciation, her placement next to two Magi alludes to the Adoration of the Virgin; two scenes that are missing from the niches above and which would be fitting for a narrative cycle of the Infancy of Christ and Life of Mary. As in the representations of the standing Mary and Joseph in the uppermost row of gabled niches, the large figures of the bottom row function as visual brackets, directing the viewer's attention into the centre of the structure, where a cult image would have been placed between the two sets of doors.

When the doors are closed, there appears a large painting of Saint Paul holding his sword and pointing away from himself on the right-hand panel (Fig. 6). Unfortunately, the condition of the painting on the back of the door on the left is too poor for an accompanying image to be reconstructed, though it likely displayed an image of Saint Peter who is conventionally paired with Saint Paul (Gardner, 1994, p. 17). The backs of the central panels of the Saint Catherine Polyptych are covered with red paint, evenly speckled with yellow-coloured brushstrokes (Fig. 7). This abstract pattern may suggest that these panels were not meant to be seen and were, instead, hidden against the back wall of the altar space. According to a conservation report, such placement against a wall also helped to preserve painting on the back of another set of polptych doors now housed at a church dedicated to Saint James in Yurre (Álava). The backs of these panels were discovered to be ornamented with a pattern of small blue flowers on red ground during conservation efforts in 1989 (Mirari, 1989, p. 188). The edges 
of the Saint Catherine Panels retain fragments of a painted pattern of heraldic lions and castles, also found on surviving panels housed elsewhere and discussed below.

Indeed, the majority of the panels' features, from their general layout to most of their compositions, are echoed in other surviving panels from medieval Castile, a corpus to which these doors clearly belong. Other features of the doors, however, are unique, such as the painting on their exterior, the inclusion of an isolated female saint and several other small details within the narrative scenes. Both the panels' aberrant and commonplace attributes make them an important discovery for the study of altar furnishings from medieval Castile. Their commonalities with other panels shows that wood altar panels displaying small groups of figures housed in ornamented niches were more common than previously believed. Their unique qualities provide new material evidence that such panels were created by distinct artists and hints at the likely variety of such altar frontals and altarpieces across northern Castile.

\section{SURVIVING CARVED ALTAR PANELS FROM MEDIEVAL CASTILE}

A surviving group of wood panels with provenance linking them to the region around Burgos share numerous features in common: they are comprised of small wood carvings and polychromed and display figures or groups of figures within architectonic frames (Fig. 8). These common and visually prominent features give the impression that the surviving panels are closely, if not directly related to one another. And yet, small differences amongst the panels challenge the likelihood of direct links between them. Of great importance is the fact that the modelling of robes, spacing of figures within compositions and design of framing ornamentation are slightly different in each of the surviving panels. Indeed, no two panels or sets of panels share exact dimensions nor the same combination of ornamentation and figures. The group can be divided, however, into three general categories: polyptych doors and fragments thereof; panels that survive individually; and pairs of altarpieces and frontals.

Small yet ubiquitous discrepancies amongst the corpus suggest that the panels were unlikely produced by a single workshop and point, instead, to a network of artists working across northern Castile. Similarities amongst their general design could have resulted from the circulation of models in the form of individual and easily portable carved pieces of wood, of which the panels are comprised. Once a commission had been secured - and with it, specifications regarding dimensions 
and iconography - artists transformed these models into new figures and scenes, adjusting compositions and incorporating certain artistic flourishes. The same process could be applied to the architectonic borders that surround figures and scenes in all surviving panels. Here, like in the figural groups, artists conformed to a certain general type: borders comprised of crenellations bracketed by turrets that fill the spandrels of the inner frame. And yet, once again, no surviving architectonic border is exactly the same, each representing the idiosyncratic touch of the artist.

The design and creation within one workshop of so many borders, figures and compositions with subtle differences would diminish the practical benefits of working in such a contained environment. It is more likely that these panels point to a popular style of altar furnishing prevalent across northern Castile. The addition of new works to the corpus therefore affirm that altarpieces and frontals of different sizes and iconography could be found in Castile prior to the development of gigantic and flamboyant altarpieces in the fifteenth century.

\section{CLOSABLE POLYPTYCHS}

The Frederic Marès Museum in Barcelona houses a closable polyptych that contains numerous features that closely resemble those of the Saint Catherine Panels (Fig. 9). The work comprises two sets of gabled doors containing small niches in which figural groups are set surrounding a large central structure 220 centimetres tall with a base that is $5 \mathrm{I}$ x 79 centimetres. Similarities between this work and the privately-owned panels suggests that those displaying an image of Saint Catherine were likely also doors to a central structure. The Marès polyptych was first recorded at a hermitage dedicated to the Virgin of the Fields at Castildelgado, a small town along the pilgrimage route from Santo Domingo de la Calzada (La Rioja) to Santiago Compostela (Huidobro Serna, 1950, pp. 34-37). Publications by the Marès museum date the work to circa 1300 (Español Bertran and Yarza Luaces, I991, p. 393).

The uppermost left-hand niches of the Marès and Saint Catherine sets of doors contain the same narrative scenes: The Visitation of Saint Elizabeth and her cousin and the Nativity of Christ (Figs. 3, IO, II and I2). Indeed, even the layout of figures and furnishings are the same in both sets of panels. For instance, both depictions of the Nativity show Mary in bed propping herself up with her right arm and accompanied by Saint Joseph at her feet. An altar-like structure (or feeding trough) appears behind the bed, almost as if they were rising directly 
from Mary's midsection. This arrangement of principal features is also repeated in all but one depiction of the Nativity within the surviving corpus. There are also small, yet important, differences amongst the representations of this scene. In the Castildelgado panels, for instance, Mary has a female companion who crouches under an arch of the surrounding frame. In addition, the altar-like structure at the centre contains a small ox and donkey. In the corresponding section of the Saint Catherine Panels, a small representation of the infant Jesus can be found here instead and the narrower dimensions of the scene mean that there is insufficient room for a female companion. In the Saint Catherine Panels, the figures of Joseph and Mary are brought closer together, more clearly appearing to interact with one another.

One explanation for the difference in the spacing of figures is hinted at by the existence of small platforms along the bottom of the compositions in the Saint Catherine Polyptych - a feature that can also be found in most extant panels from this corpus. The loss of polychromy on some groups of figures reveal how they were carved from single blocks of wood that were then added to the corresponding niches. The small platforms represent the common ground from which the images were carved. This method resulted in greater uniformity in the representation of space amongst the compositions of the Saint Catherine Polyptych, in which the lower halves of the figural groups are denser as the robes and feet of the figures are linked both to one another and to the lower edge of the corresponding block of wood. The spacing of figures in the Castildelgado niches is more irregular. In some places, the figures are pressed against the arches of their niches, as in the scenes of the Nativity and Massacre of the Innocents. In other places, for instance, the compositions include isolated figures on horseback, a possibility that seems to have escaped the Saint Catherine artist who placed a tree behind the donkey of the Flight into Egypt, in order to reinforce the physical connection between the scene and the wood block from which it was carved. These variations may point to substantially different modes of production: while the artist of the Saint Catherine panels had to fit all the figures of a scene onto a block of wood, the Castiledelgado artist may have been able to carve his figures out of the very panels that made up the structure, allowing for more spatial variety within individual niches.

Of the narrative scenes included within the two uppermost rows, only two are not repeated in both sets: the Castildelgado panels include a depiction of the Dormition of the Virgin while the Saint Catherine doors contain a scene of the Holy Family's Flight into Egypt. The rest of the scenes are represented in both works and include, in most cases, the same compositions. Significant differences 
in the iconographic programmes appear, however, in the arrangement of figures along the bottom rows. In the Castildelgado set, this section includes the Adoration of the three Magi, Saint Joseph and the Annunciation.

On the left of the structure, the three Magi are depicted as if they are approaching the central image, holding out before them the precious vessels they have brought as gifts. On the right side, Saint Joseph also kneels towards the central structure, head in his hands as if he were contemplating the words spoken to him by an angel: 'Joseph, son of David, fear not to take unto thee Mary thy wife, for that which is conceived in her, is of the Holy Ghost. And she shall bring forth a son: and thou shalt call his name JESUS. For he shall save his people from their sins.' (Matthew I:2O-2) (Fig. I3). The position of the archangel Gabriel behind Joseph draws a visual link between his vision and the Annunciation to the Virgin, in which the name of Christ is also central: 'The Holy Ghost shall come upon thee, and the power of the most High shall overshadow thee. And therefore also the Holy which shall be born of thee shall be called the Son of God' (Luke I:35). ${ }^{1}$ Indeed, the placement of the Annunciation behind Joseph transforms it into a stand-in of sorts for Joseph's vision.

The alternative arrangement and designs of the figures along the lowest register of the Saint Catherine doors raise several important questions. Next to Saint Catherine, Joseph becomes a sort of devotee of the female saint who, like him, also had visions related to the Virgin and Christ. On the right-hand panels, the figures appear as participants in the Annunciation or Adoration of the Magi. As a depiction of the latter, the scene is missing one magus; if representing an Annunciation scene, the standing Virgin is missing her infant and holds a Bible instead. Similarities between this large female figure and the Virgin in the Annunciation scene in the Castildelgado panels and in the third surviving set of polyptych doors housed at Yurre, suggest the likelihood that its design was based on a model. And yet, why the Saint Catherine artist used such a model cannot be known. Perhaps the inclusion of a Virgin and Child in this niche would have appeared redundant if the image housed in the now-missing central structure was also a Virgin and Child. Alternatively, this representation may not be of the Virgin at all but of a monastic patron or other female saint linked, to the monastery or convent for which the panels were commissioned. The resemblance between this large figure and the Virgin of the Annunciation may have resulted from the adaptation of available models. The design of the smaller Saint Catherine figure

See also Luke I:3I-34. 
also appears to hint at the adaptation of models as her head and face mirror those of the youngest Magus in the niche above (Figs. 2 and 5).

A single extant carving held in storage at the Marès museum provides some idea of what portable models looked like (Español Bertran and Yarza Luaces, I99I, pp. 250-5I) (Fig. I4). Measuring 28 x 37 x 5.5 centimetres and lacking any traces of polychromy, the carving depicts the Nativity. The arrangement of elements in this scene - the placement and posture of the Virgin in bed; the figure of Saint Joseph at the foot of the bed, head bent downwards; and the protruding structure at the centre - is identical to almost all other representations of this scene. The repeated, angular folds of Mary's bedsheets, however, are singular, as are the receding perspective of her bed and the fullness of Joseph's robes. Given its small size and light weight, this and related carvings could have easily circulated across northern Castile. Indeed, the models used at Yurre and Castildelgado did not have to travel far, these two sites being only some seventy kilometres apart (Fig. 8). This proximity may explain the substantial iconographic similarities between the two sets of doors. The combination of common and aberrant features in these panels point to an intricate process of design and assemblage in which the requirements of the patrons and abilities of the artists were negotiated.

Indeed, the Saint Catherine Panels includes several notable instances of artistic flourishes. Behind the pair of knights in the scene of the Massacre of the Innocents, for instance, there is a small, cowering infant, whose posture exposes his posterior towards the outer edges of that door (Fig. I5). The infant's genitals become clearly visible when one closes these doors. Like the representation of Joseph's hand on Mary's knee or the inclusion of a canine-like demon behind King Herod's ear, this exposed backside is a detail not found in other panels. Such embellishment details suggest that, though models were copied and compositions and scenes repeated, artists could also incorporate distinct features or make alterations that reflected their idiosyncrasies. Such touches provide important material evidence of the existence of numerous artists producing these types of altar furnishings.

The Saint Catherine Panels also provide unparalleled material evidence of another important facet of the construction of these closable polyptychs; it is the only extant set of doors upon which paintings of figures can still be seen on the exterior. The fact that the Castiledelgado panels could be closed has raised questions regarding the type of images that would be displayed on their exterior. In his study of medieval closable polyptychs, Mojmír Frinta puts forth the possibility that three painted panels in the collection of The Metropolitan Museum 
of Art in New York functioned as the outer faces of the Marès doors (Frinta, I967, pp. III-I2). ${ }^{2}$ Though he overlooked the differing dimensions of the two sets of panels (New York: 4I x 26.7 centimeters; Barcelona: 5I x 29 centimeters), his hypothesis appears well-founded when considered in light of the Saint Catherine Panels. The loss of paint along the edges of these reveals the joining of the interior and exterior faces of the polyptych and shows that painted panels were indeed joined to the exterior of such structures, as Frinta hypothesised. ${ }^{3}$ The survival of another panel displaying a standing figure of Saint Paul at the cathedral of Ávila further suggests that other exterior paintings such as those on the Saint Catherine Panels were in circulation across northern Castile (Fig. I6) (Post, I930, II, pp. 156-57). Conversely, the survival of such paintings on the Saint Catherine doors advances the likelihood that the Ávila and New York City panels were once part of yet other now-lost polyptychs.

The painted borders of the Saint Catherine panels also display the coats of arms of the kingdoms of León and Castile, which were reunited in I230, providing a post quem for dating these works. As Francisco Javier Hernández has argued, the coats of arms of León and Castile held territorial as well as dynastic meaning (Hernández, 20I2, pp. 4IO-II). They did not solely represent a single family line in the manner of the Capetian fleur-de-lis, but functioned rather as royal symbols and as ideograms for the kingdom as a whole. It is notable, therefore, that a substantial number of both wood-carved and solely painted panels - including the large Castilian altar ensemble now in the collection of the Chicago Institute of Art and commissioned by Pedro López de Ayala in 1396 - have provenances linking them to the province of La Rioja, a territory whose dominion was often contested by the kings of Navarre and Castile throughout the twelfth, thirteenth and fourteenth centuries (Northern European, 2008, pp. I00-07; Turza, 2007, p. 39). ${ }^{4}$ The conspicuous display of Castilian coat of arms on these panels, along the

2 Photographs of these panels can be found in the online catalogue of The Metropolitan Museum of art. In this catalogue, the panels are described as "Scenes from the Life of Christ: Arrest of Christ, Christ in Limbo; Descent from the Cross, Preparation of Christ's Body for His Entombment". See https://www.metmuseum.org/art/collection/search/471722 and https://www. metmuseum.org/art/collection/search/471999.

${ }^{3}$ In the case of the Saint Catherine panels, however, the edge bearing coats of arms is attached to the interior faces, in which the figural groups are set. This situation is reversed on the New York panels, where the heraldic edges are attached to the painted panels. This may suggest that these panels did not function as external faces of a polyptych, unless there was simply more than one approach to attaching painted exteriors.

${ }^{4}$ It was also a region that was frequented by pilgrims on the road from France to Compostela (Turza, 2007). 
edges of the two largest surviving carved panels, discussed in the following section, and on a painted panel featuring Saint Christopher now in the collection of the Prado Museum in Madrid, may suggest that they also originated in this region, commissioned by patrons who wished to exhibit their political alliances on these large works of art.

\section{PAIRS AND SINGLE PANELS}

Additional panels, fragments and groups of figures further augment understanding of this tradition and provide yet more evidence of how wood altarpieces and frontals in medieval Castile were adapted to suit numerous different contexts and requirements set out by patrons. Measuring $93 \times 222 \times 6.5 \mathrm{~cm}$ and $93.5 \times$ $228 \times 6.5 \mathrm{~cm}$ centimetres, two panels that went on display at the Museo Nacional de Catalunya (Barcelona) in 2016 are the largest extant examples of carved wooden polypytchs from Castile. ${ }^{5}$ Like other members of the corpus, each panel is divided into compartments framed by trilobed arches with crenellated turrets in the spandrels, while the groups of figures within each niche rest on small platforms. In general, the arrangement of figures and furnishings of the scenes also resembles those in representations of the Visitation, Nativity, Annunciation to the Shepherds and Presentation at the Temple in other surviving panels. In addition, the patterns of rosettes and coats of arms in the outer borders mirror those found on panels in the Prado collection, discussed in further detail below, and the Saint Catherine Panels respectively. And yet, the groups of figures on the large MNAC panels appear far smaller than their surrounding frames, the interior arches of which are relatively shallow. ${ }^{6}$

The dimensions of the two large MNAC panels also make it difficult to determine their original arrangement around the altar. Their vertical orientation makes it reasonable to presume that they were not used as frontals. Though they have survived as two separate panels resembling the doors of a large polyptych, their dimensions (and, presumably, their weight) also make it unlikely that they

5 For an image of these panels, see http://www.museunacional.cat/en/colleccio/panels-retablechildhood-christ/anonim-castella/251549-cjt .

${ }^{6}$ Ibid. The extent to which the polychromy is original is unknown, as is the provenance and date, though the MNAC's curators date the work to the fourteenth century. 
were opened and closed. ${ }^{7}$ Rather, they may have served as immobile lateral panels to a central structure or may have been part of a larger ensemble of panels mounted on the apse of a chapel. Likely matching the dimensions of the space in which were originally set, these panels provide singular physical evidence of the customisation of panels for different contexts. In this case, it appears as though, despite the request for very large panels, the artists failed to find sufficiently large models for the figural scenes. As a result, the figures appear to float within their niches, an effect that may have appeared less striking if the supporting panels had originally contained painting or gilding, as seen behind the figures of the large panel that once belonged to the high altar of the cathedral of Santo Domingo de la Calzada in La Rioja (Fig. 17) (Cook, I950, p. 333 n. 7).

The iconographic programme of this panel survives in poor condition and was reconstructed by Walter W.S. Cook in 1950. According to his reconstruction, it displayed scenes from the Books of Genesis and Exodus and from the events leading to Christ's arrest in the New Testament. This programme does not appear on any other surviving carved panel, though small compositional similarities exist between some of its scenes and those also representing the Book of Genesis on a painted closable polyptych from Añastro, only fifty kilometres north from the Riojan cathedral (Fig. 8). ${ }^{8}$

Exact explanations for the Riojan panel's iconographic programme or the MNAC panels' imposing dimensions cannot be provided without further investigation. Their survival does present certain important possibilities, however. The MNAC panels show how large panels could be that were produced using the same techniques of carving wood figures and borders as employed in the creation of the Saint Catherine Polyptych. They also hint at the assemblage of panels into different ensembles. Finally, these panels obfuscate any direct or logical corollaries between size, dimension and iconographic programme; in one case, panels so large that their original location is difficult to decipher nevertheless display common images seen elsewhere, while in another, a panel whose dimensions strongly suggest that it may have served as an altar frontal, displays a highly sin-

${ }^{7}$ I was unable to see evidence of hinges, which would have to have been large enough to bare the weight of these panels. A close inspection and view of the back of the panels was not possible, however.

${ }^{8}$ The panels of a retable dedicated to Saint Andrew and originally from a parochial church in Añastro (Burgos), are distributed amongst the collections of the provincial council of Burgos, The Metropolitan Museum of Art and the Museo Zuloaga de Zumaya (Basque Country). For an image of the central panel displaying images from the Book of Genesis and more information on the work, see https://www.metmuseum.org/art/collection/search/472322. 
gular and complex iconographic programme. As part of this corpus, these panels make clear that any combination and permutation of attributes and imagery was possible.

The survival of two sets of altarpieces and frontals provides further evidence that panels were not always displayed alone but may have belonged to larger ensembles. They also offer additional information regarding the availability and circulation of models. The altarpiece and frontal in the Prado collection display scenes from the life of John the Baptist, who was likely also represented at the centre of the altarpiece (Fig. I8). Like the scenes of the Calzada panel, this iconographic programme is not repeated in any other surviving carved panel. This makes it difficult, therefore, to draw general comparisons between its figures and compositions with those from other extant examples. Some small details are worthy of note, however. For instance, the representation of Saint Elizabeth in her bed shows her propped up on her arm like the Virgin in scenes of the Nativity elsewhere (Fig. 19). Likewise, representations of Herod II in discussion with Saint John show him seated legs crossed on a throne as do depictions of Herod I in the Saint Catherine Panels (Figs. 5 and 20). Besides these small compositional similarities, however, the modelling of the tetrarchs' thrones, robes and crowns differ.

A second ensemble now in Burgos cathedral displays some of the most striking similarities and differences with the remainder of the corpus (Fig. 2I). Though its general format and dimensions resemble those of the pair at the Prado, its iconographic programme is far from aberrant being closely related to surviving polyptychs and to the large panel from Santo Domingo de la Calzada. Like the former, the altarpiece of the Burgos ensemble displays scenes from the life of the Virgin around a central structure. The central compartment of the frontal contains traces of a mandora surrounded by four symbols of the Evangelists, not unlike those represented at the centre of the Calzada panel. In addition, both the Burgos and Calzada panels are framed by borders containing rosettes which are themselves surrounded by a thinner rope-like perimeter. These ornamental features can also be seen on the Prado altarpiece and frontal.

The altarpiece and frontal now at Burgos cathedral were originally housed in the Benedictine church of Santa Maria in Mave (Palencia) and moved from a chapel on the southern side of that church's nave to Burgos cathedral in I93I, where they were placed in the cloister until they were moved to their current location in the chapel of Saint Nicholas sometime after 1993 (Ara Gil, 2002, p. Io; Navarro García, I930, p. 220). A photograph survives of the panels when they were still at Mave, helping both to confirm the work's provenance and reconstruct some of the iconography of 
the altarpiece. ${ }^{9}$ Its original display at Mave puts it west of Burgos and further away from the Riojan borders than the other panels discussed above, augmenting the expanse of territory in which models for these panels were likely circulated (Fig. 8).

The city of Burgos is home to yet another set of carved wood panels with special importance in dating the corpus. These panels belong to the wooden sepulchre of Sancho Sánchez de Rojas, who died at the battle of Nájera in 1367 (Ruiz Maldonado, 2005, pp. 206-08) (Fig. 23). His tomb was created in the fourteenth century and was first housed at the Cistercian monastery Vileña, near Burgos. The monastery suffered a fire in 1970 but, because of its placement against a wall, the carved wood panels of this sepulchre were protected and consequently moved to the Museo del Retablo in Burgos. In addition to similarities between the panels' layout of figural groups within arches ornamented with crenellations in the spandrels, some of the figures resemble those seen elsewhere. For instance, the grieving figures in the central scene along the front of the sepulchre pull their hair like the grieving mothers in the representation of the Massacre of the Innocents in the Castildelgado polyptych and in a fragment of a polyptych in storage at the Marès museum (Figs 9, 24 and 25). In each of these cases, the scene is also marked by the close placement of figures, like the mourning Apostles in the Virgin's Dormition in the Castildelgado panels. Finally, the lid of the sarcophagus, which supports an effigy of the deceased, is surrounded by a rope-like border similar to those of the Mave and Prado ensembles. While exact dates for the corpus of surviving panels discussed previously cannot be deduced from this sarcophagus, it can be inferred that these works were likely created around the same time as this sarcophagus, that is, in the middle of the fourteenth century.

\section{SCHOLARSHIP ON CASTILIAN PANELS AND ON THE DEVELOPMENT}

OF ALTARPIECES IN MEDIEVAL EUROPE

Scholarship on Castilian panels has largely focused on dating individual panels in order to fit them to a chronology that links the development of the altarpiece in

9 For this photograph, see Navarro Garcia, 1930, p. 157. The photograph also shows, however, the altarpiece and frontal united into a single panel. It is possible that they were reinstalled in this fashion from a previous position in which the frontal would have been separated from the altarpiece by the altar-table. Perhaps this was their arrangement around the church's high altar which, when Navarro Garcia visited the site before his publication of this photograph, had been furnished with a 'modern' altarpiece (Navarro Garcia, 1930, 219). 
Iberia to the Fourth Lateran Council in I215. Cook's article from 1950 provides an interesting and important example of this approach. In it, the author focuses on three carved wood panels including the large frontal from Calzada as well as two more panels from the collections of the Biblioteca Museo Balaguer (Barcelona), the Museo Arqueológico (Madrid) (Cook, 1950, pp. 33 I and 333). These last two, according to the author, are archaic in style and iconography and may represent 'Romanesque' panels. While their designs are far more pared down than the other works making up the corpus, conclusively dating them to an earlier period would require more than stylistic analysis. Rather, it is possible that the artists who created the panels at the Biblioteca Museo Balaguer or the Museo Arqueológico may have worked from models with more limited circulation or may, indeed, have had less experience with the production of these types of objects.

Cook's interpretation of these two panels as archaic in style and form is indirectly based on his more general belief that altarpieces developed as a consequence of the sanctioning of the doctrine of Transubstantiation at the Fourth Lateran Council in I215. According to this hypothesis, the ability to view the sacrament took on added importance because of the doctrine's emphasis on the sacred nature of the Eucharist. This concern for greater visibility supposedly led to the development of such practices as the elevation of the Host above the head of the priest (Binski, 1999, p. 4; Kroesen, 2009, pp. 323-36; and Williamson, 2004, pp. 343-47). The altarpiece consequently developed in order to draw the viewer's attention to that critical and miraculous transformation of the Host into the Body of Christ. With the growing importance of the altarpiece, the frontal became a less valued space upon which to display imagery. For this reason, Cook identifies these relatively unadorned panels as frontals; that is, as panels representative of an outmoded form of altar furnishing and thus simplistic in their appearance. Writing one of the first articles to provide a careful analysis of carved Castilian altar panels from the thirteenth and fourteenth centuries, Cook introduced hypotheses - as well as problems - that were to characterise future studies of Castilian altarpieces and frontals..$^{10}$ In addition, his aim of establishing a clear linear development from a very limited pool of examples was uncritically taken up by later scholars.

Adherence to these propositions and approaches can be seen in the work of Clementina Julia Ara Gil, the only scholar to attempt a broad study of thir-

10 Castińeiras provides an important critique of Cook's theories in relation to Catalan works (Castiñeiras, 2007, 124-25). 
teenth- and fourteenth-century Castilian altarpieces and frontals of carved wood (Ara Gil, 2002 and 2006). Indeed, her work on these panels focuses primarily on relating their development to the Fourth Lateran Council. The consequent change of focus from frontals to altarpieces explains, in her view, why frontals developed from the display of sacred iconography, such as Christ in Majesty, to the depiction of secondary narrative scenes supplementing sacred images now on the altarpiece. Ara Gil employs this line of reasoning in her analysis of the pair of panels now displayed at Burgos cathedral, dating the frontal earlier than the altarpiece: I235-I260 and circa 1300 respectively. The figures in the retable, according to Ara Gil, are far more dynamic and their robes are more masterfully executed than the seated apostles of the frontal (Ara Gil, 2002, p. I2). The altarpiece must therefore have been created after the elevation of the Host became a common feature of the mass; that is, after sufficient time had elapsed for decisions made at the Fourth Lateran Council to become reflected in the design of Castilian ecclesiastical interiors (Ara Gil, 2006, pp. 179, 65-66). As in Cook's study, the frontal, in turn, represents an older form of altar furnishing and is dated before such adjustments had been made to Iberian liturgical ritual.

More comprehensive attempts to study the development of the Iberian altarpiece have been spearheaded by Judith Berg Sobré and Justin Kroesen (Berg Sobré, 1989 and Kroesen, 2009). In both cases, these authors have attempted to introduce new overarching methodologies: Berg Sobré has proposed that studies of the altarpiece should be modelled on codicology, while Kroesen has emphasised the historical contexts surrounding these works of art. The former offers some instructive points, especially regarding the importance of frames and supports in the examination of the altarpiece. Berg Sobré also mentions briefly her belief that the only extant early Castilian retables are of the sculpted type, though she does not examine any of them (Berg Sobré, 1989, p. 134). Unable to find sufficient extant samples of thirteenth- and fourteenth-century Castilian altarpieces and frontals, the author concludes that it is 'unclear if the Castilian and Leonese painters ever produced the volume of retables that their counterparts did' (Berg Sobré, 1989, pp. 133-134). Like Cook and Ara Gil, her chronology for the evolution of Spanish altarpieces from the Romanesque frontal to the elaborate fifteenth-century retablo is also based on the theory that the altarpiece developed in response to the Fourth Lateran Council of I2I5 (Berg Sobré, I989, p. 4). She follows the belief that the elevatio became a widespread means of visually drawing attention to the sacrament. After this shift, the altarpiece continued to develop into progressively taller and more vertical forms, a development that the author traces carefully in her book. The concurrent production of the panels and 
polyptychs described above would have substantial implications for Berg Sobrés approach.

In his study of the context and environment in which the Iberian altarpiece developed, Kroesen similarly emphasises the importance of the visibility of the Host during mass. In his brief description of the panels at Burgos, therefore, he also dates the frontal a few decades earlier than the altarpiece (Kroesen, 2009, p. 54). Unlike other authors, however, Kroesen provides concrete textual evidence of concern with the visibility of the Host amongst Iberian clerics. The evidence in question comes from the cathedral in Girona, where a document dated to I3I3 stated that the cathedral's chapter augmented the structures around their high altar to specifically ensure that worshippers could more clearly see the elevation of the Host (Kroesen, 2009, p. 327, n. I23). Kroesen relies on this document as the basis for his view that the Iberian altarpiece developed in response to the Fourth Lateran Council, though perhaps not in the 'sense of direct prescriptions' and despite the fact that Eucharistic themes in altarpiece iconography were 'veiled [and] indirect' (Kroesen, 2009, p. 330). While the evidence from Girona provides valuable insights into the concerns of that chapter, it is also an example of Kroesen's reliance on predominantly Catalonian material for his most significant conclusions. Further research into fourteenth-century Castilian art must be conducted before parallels can be securely drawn between these two Iberian kingdoms.

Scholars who have focused on the development of the altarpiece in other regions of Europe have effectively challenged the theory that altarpieces developed in response to the Fourth Lateran Council, a position whose history and shortcomings are comprehensively outlined in publications by Paul Binksi, Julian Gardner and Beth Williamson. These authors have pointed out, for instance, that altarpieces are not explicitly mentioned in ecclesiastical legislations and were likely not viewed, therefore, as requisite components for the proper use of the altar. The belief that altarpieces developed across Europe in direct response to the concerns expressed at the Fourth Lateran Council therefore over simplifies the relationship of medieval worshippers to their altars (Binski, 2009, p. 32; Gardner, I994, pp. 6 and I3; Williamson, 2004, p. 347). Rather than abiding carefully to foreign and gnomic prescriptions, it is more likely that clerics celebrated at altars in ways that suited their physical and cultural contexts. According to these studies, alternative catalysts for the development of altarpieces include lay

II With regards to the visibility of the Host, Kroesen's sources come from Segovia (I2I6), Girona (I313), Badajoz (I5OI) and Tuy (I528) (Kroesen 2009, 326-327). Next to these, other documentary evidences now regarding to liturgy and architecture, in Carrero Santamaría, 2009. 
patronage and burgeoning interest in saints' cults. The corpus of surviving polyptychs, altarpieces and frontals from fourteenth-century Castile provide material evidence that accords with these perspectives. Indeed, the range of sizes, shapes and iconographic programmes represented in the corpus introduce important material examples of the key roles of saints' cults and local context in the design and development of altarpieces in Castile as well.

The representation of Saint Catherine along the bottom row of the privatelyowned polyptych is a notable instance of the adjustment of imagery in order to meet the devotional needs of corresponding communities. In addition, strong similarities between the iconographic programmes of the Saint Catherine doors and those from Yurre and Castildelgado suggest that patrons may have been aware of the availability of carvings of the life of the Virgin. The aberrant inclusion of an image of Saint Catherine amongst the larger figures of the bottom register hints at input from those who intended to use this set of panels for the veneration of both that saint and of Mary.

CONCLUSION

The Prado Museum in Madrid acquired its altarpiece and frontal displaying scenes from the life of John the Baptist from the Várez Fisa Collection in 2013 and, in 2016, the MNAC received the loan of the two very large panels containing scenes from Christ's infancy and bearing the coat of arms of Castile and León. The photographic collection of the Institut Amatller d'Art Hispànic, Barcelona, contains images of yet more fragments and figures that likely once belonged to panels similar to those discussed in this study, such as a set of three polyptych doors, the current location of which is not known. A great deal more work will have to be conducted for a better understanding of the reasoning behind certain combinations of narratives and additions of unique details. Panels for which some provenance is known usually originated in small churches or monasteries. In contrast, there is scant evidence, visual or textual, of thirteenth- and fourteenthcentury altarpieces from cathedrals in Castile. Only a small number of cursory documents relating to their commission and eventual replacement with modern retables hint at their former existence. While inventories provide some entries for panels and textile frontals, they provide limited evidence for objects that can unambiguously be identified as altarpieces. It is possible that the generally static nature of such large panels meant they were not inventoried by sacristans and treasurers. Furthermore, having little liturgical function meant that they would 
not have been described in ceremonial rubrics either. The search for additional information would seem likely to begin, therefore, in small church archives.

Yet, in his study of workshops in medieval Catalonia, Manuel Castiñeiras proposes that master artists were likely based in large cities and created panels there that were then distributed to smaller parish churches (Castiñeiras, 2007, pp. 126-27). While concrete evidence for such workshops has yet to be found, Burgos was certainly a large enough city to have housed such communities of artists, who could have likely also found work at Las Huelgas monastery and at the cathedral itself. ${ }^{\mathrm{I2}}$ The survival of wood-carved sarcophagi in Burgos provides additional material evidence of the importance of this city in the creation of these types of works. It is likely that, along with the discovery of new works, further investigation will produce intriguing material with which to address these and other important questions.

This group of carved wood panels shows that the exclusion of Castile from discussions of the development of altarpieces and frontals in medieval Europe is no longer warranted. This study has drawn attention to both similarities and differences amongst the panels and considered how these may have arisen through the circulation and adaptation of models amongst various artists and workshops. This view of workshop practices offers a counterpoint to previous studies of the Castilian altarpiece that have forced surviving panels into restricted chronologies or art historical narratives. These panels' diversity demonstrates that they were the products of a rich artistic environment comprising patrons with differing needs and artists with varying abilities. As such, they introduce important new material for current discussions of the development of altarpieces in medieval Europe.

${ }^{12}$ Gutiérrez Baños, 20I5, p. 48. 
BIBLIOGRAPHY

Ara Gil, C. J., 2002: "El retablo gótico en Castilla." In Retablos esculpidos en Aragón: del Gótico al Barroco. edited by María Carmen Lacarra Ducay, Zaragoza: Institución "Fernando el Católico", pp. 7-64.

Ara Gil, C. J., 2006: "Los retablos de talla góticos en el territorio burgalés", in $E l$ arte gótico en el territorio burgalés, coord. E. J. Rodríguez and M. I. Bringas, Burgos: Universidad Popular para la Educación y Cultura, pp. I79-2I4.

Berg Sobré, J., 1989: Behind the Altar Table: The Development of the Painted Retable in Spain, I350-I500. Columbia: University of Missouri Press.

Binski, P., 1999: "The English Parish Church and its Art in the Later Middle Ages: A Review of the Problem", Studies in Iconography, 20, pp. I-25.

Carrero Santamaría, E., 2009: "Presbiterio y coro en la catedral de Toledo. En busca de unas circunstancias", Hortus Artium Medievalium, I5, pp. 315-327.

Castiñeiras González, M. A., 2007: "Catalan Romanesque Painting Revisited: The Altar-Frontal Workshops.” In Spanish Medieval Art. Recent Studies. Edited by Colum Hourihane, II9-I53. Medieval and Renaissance Texts and Studies 346. Tempe: Arizona Center for Medieval and Renaissance Studies.

Cook, W. W. S. 1950. "Wooden Altar Frontals from Castile”, The Art Bulletin 32 (4), pp. 33I-335.

Español Bertran, F. and Yarza Luaces, J., I991: Fons del Museu Frederic Marès, Catàleg d'escultura i pintura medievals. Barcelona: Ajuntament de Barcelona.

Frinta, M. S., 1967: "The Closing Tabernacle: A Fanciful Innovation of Medieval Design." The Art Quarterly, 30, pp. I03-I7.

García Turza, J. 2007: "El camino jacobeo del Ebro a su paso por La Rioja." Brocar. Cuadernos de Investigación Histórica (31), pp. 35-78.

Gardner, J. 1994: "Altars, Altarpieces, and Art History: Legislation and Usage." In Italian Altarpieces I250-I550: Function and Design. Edited by Eve Borsook and Fiorella Superbi Gioffredi, Oxford: Clarendon Press, pp. 5-39.

Gutiérrez Baños, F., 20I5: "Una nota sobre escultura castellana del siglo XIII: Juan González, el pintor de las imágenes de Burgos, y el sepulcro de dońa Mayor Guillén de Guzmán en el convento de Santa Clara de Alcocer (Guadalajara)", Archivo Español de Arte, LXXXVIII-349, pp. 37-52.

Hernández, F. J., 2012: “Two Weddings and a Funeral: Alfonso's Monuments in Burgos." Hispanic Research Journal I3 (5), pp. 405-3I.

Huidobro Serna, L., 1950: Las peregrinaciones jacobeas. Edited by Mariano Domínguez Berrueta. Vol. 2. Madrid: Instituto de España. 
Kroesen, J. E. A., 2009: Staging the Liturgy: The Medieval Altarpiece in the Iberian Peninsula. Leuven: Peeters.

Mirari, 1989: Mirari. Un pueblo al encuentro del arte (Sala Amárica 1989-1990). Vitoria: Diputación Foral de Alava.

Mor, L., 2016: Un "retablo a portelle" intagliato e dipinto della Castiglia medievale I modelli e lo stile. Unpublished.

Navarro García, R. 1930: Catálogo monumental de la provincia de Palencia. Palencia: Impresa Provincial.

Northern European, 2008: Northern European and Spanish Paintings before I60o in the Art Institute of Chicago: A Catalogue of the Collection, edited by Martha Wolff, Chicago: Art Institute of Chicago.

Panera Cuevas, F. J., Yagüe Hoyal, P. and Parra Crego. E., 2000: La restauración del retablo de la Catedral Vieja de Salamanca. Valladolid: Fundación del Patrimonio Histórico de Castilla y León.

Muñiz Petralanda, J., 200I: "El retablo gótico esculpido." Erretaulak Retablos, pp. II6-I45.

Post, R. C., 1930: A History of Spanish Painting. Harvard: Harvard University Press.

Radelet, T., 2016: Risultati delle análisis su Polittico. Unpublished.

Ruiz Maldonado, M., 2005. "Sepulcro de Sancho Sánchez de Rojas", in Vestiduras ricas: El monasterio de Las Huelgas y su época II70-I340. Madrid: Patrimonio Nacional, pp. 206-208.

Velasco, A., Ros, E. y Gràcia, M. J., 20I3-20I4: "Un retaule-tabernacle gòtic a Santa Maria de Cap d'Aran (Tredós, Val d'Aran)”, Lambard, XXV, pp. II9I68.

Williamson, B., 2004: “Altarpieces, Liturgy, and Devotion.” Speculum 79 (2), pp. 34I-406. 


\section{APPENDIX I}

\section{Corpus of fourteenth-century altarpieces and frontals from Castile}

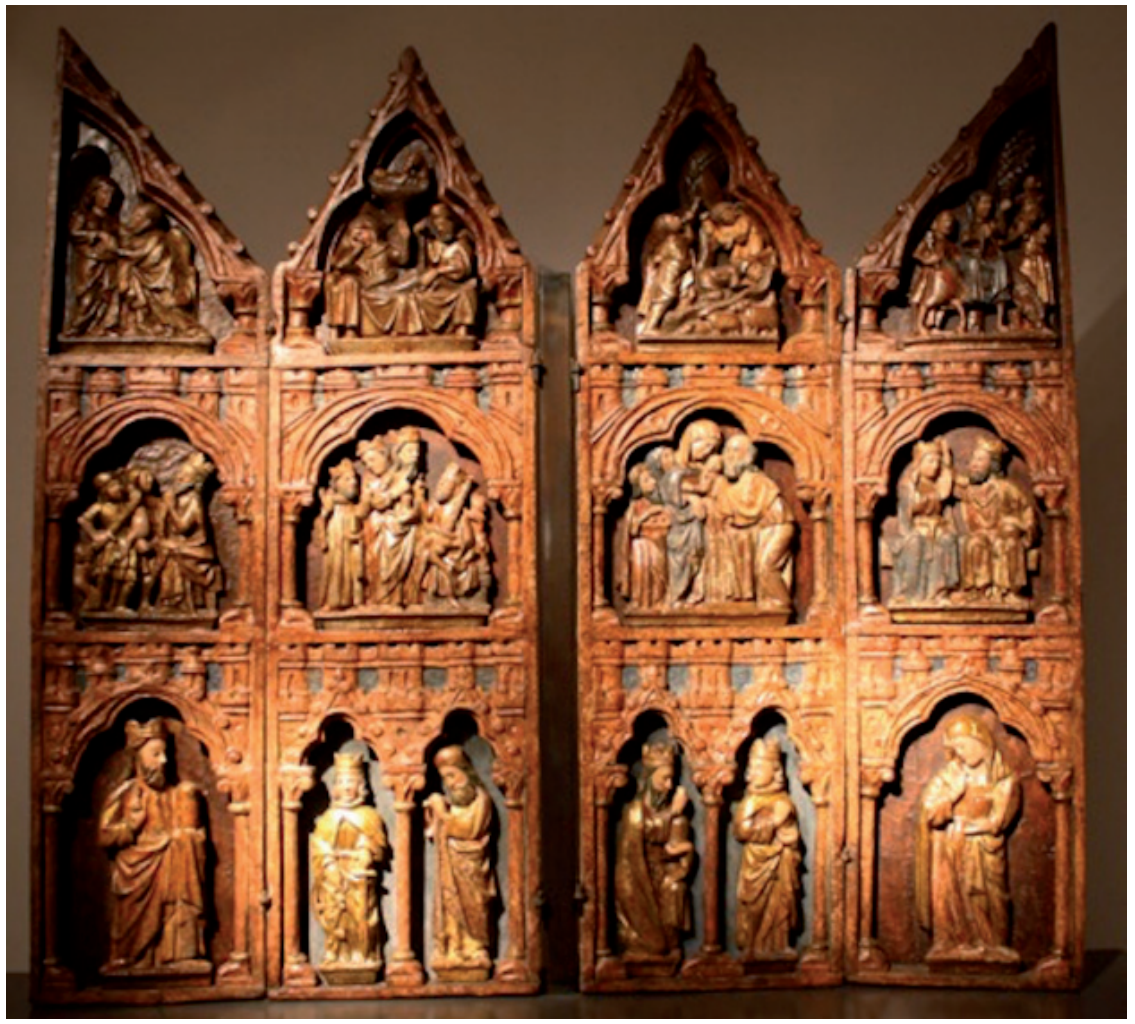

Fig. I. Polyptych doors. Polychrome wood, each door is $60 \mathrm{x} \mathrm{I} 38.5 \mathrm{~cm}$. Private collection, Dublin. Photo: Nicola Jennings. 


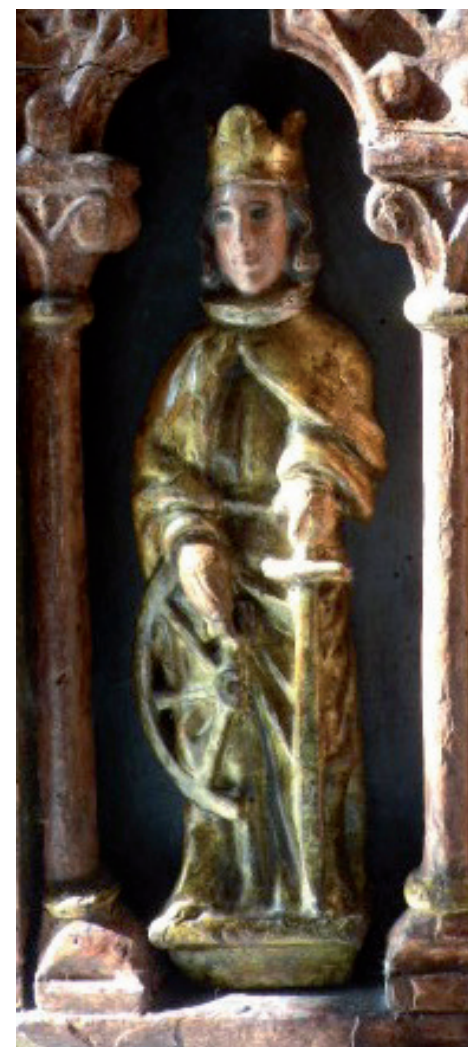

Fig. 2.

Saint Catherine figure, Saint Catherine Panels.

Photo: author.

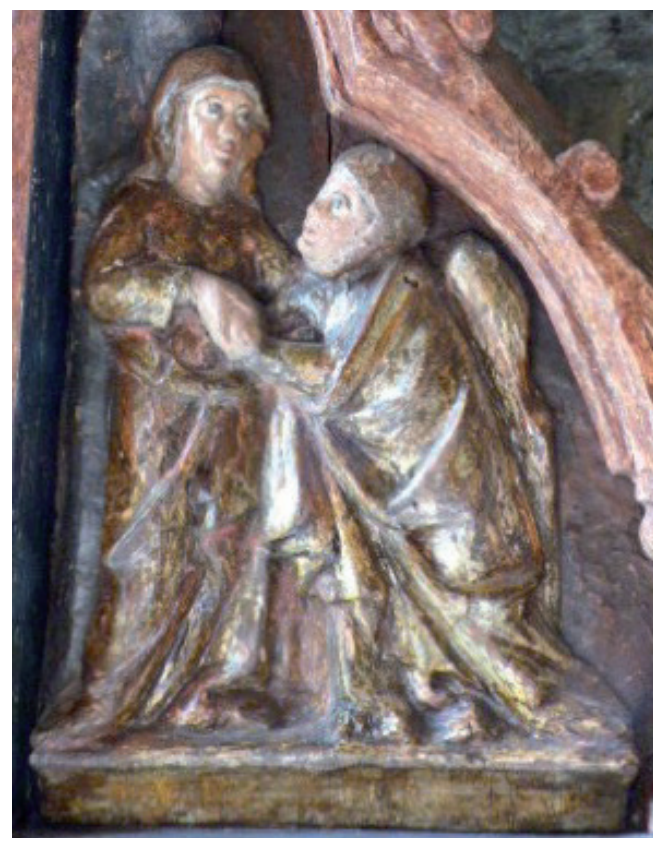

Photo: author. 


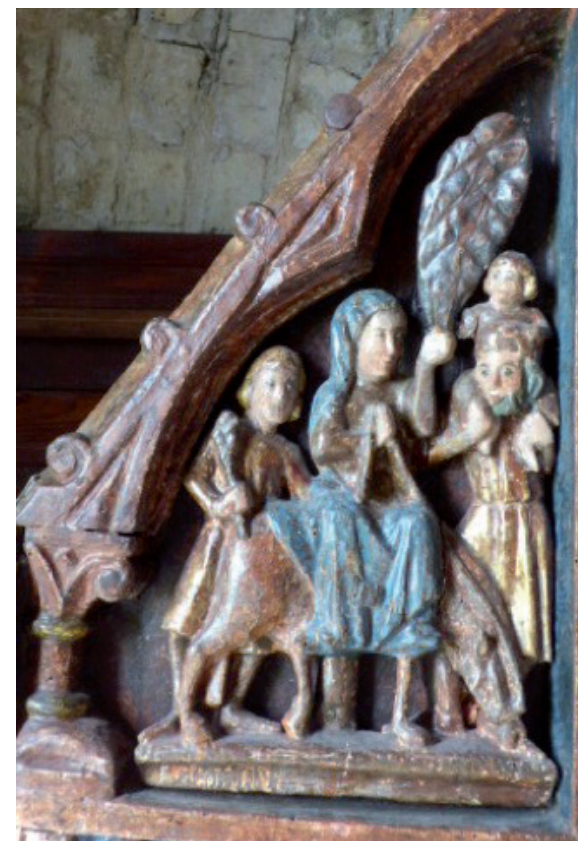

Fig. 4 .

Flight into Egypt

Saint Catherine Panels. Photo: author.

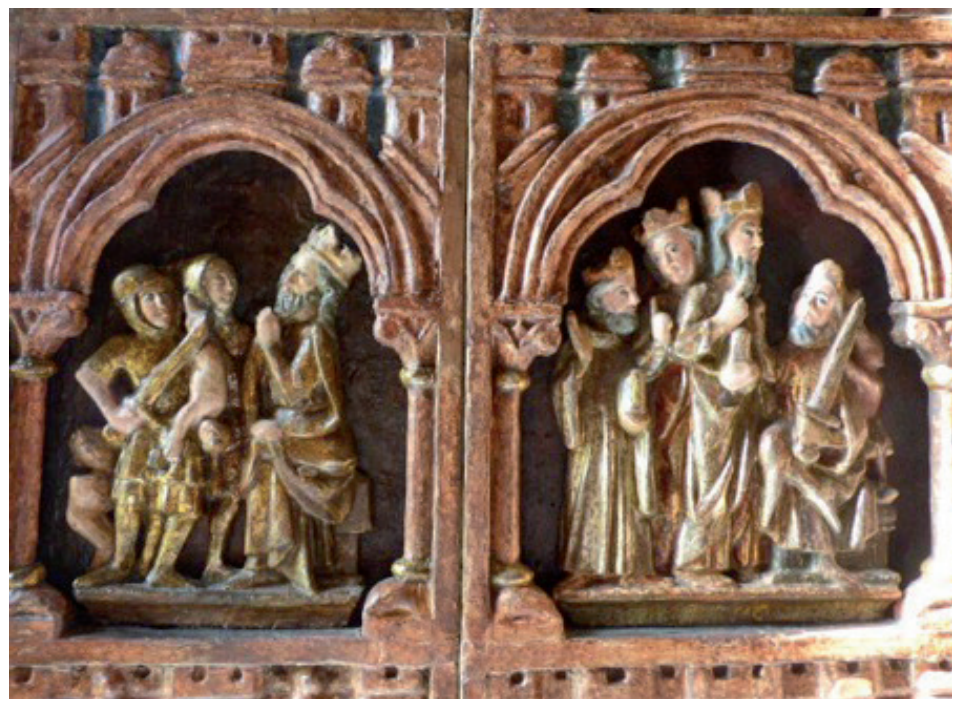

Fig. 5. Massacre of the Innocents and King Herod and the Three Magi, Saint Catherine Panels. Photo: author. 


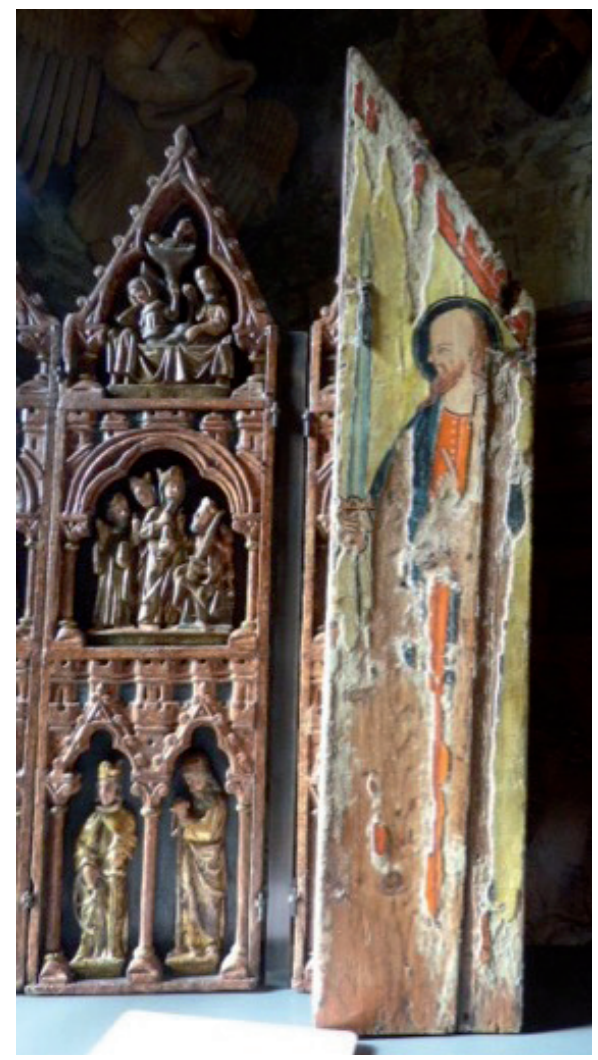

Fig. 6.

Painting of Saint Paul,

Saint Catherine Panels. Photo: author.

Fig. 7.

Back of central panels of the Saint Catherine Polyptych. Photo: author.

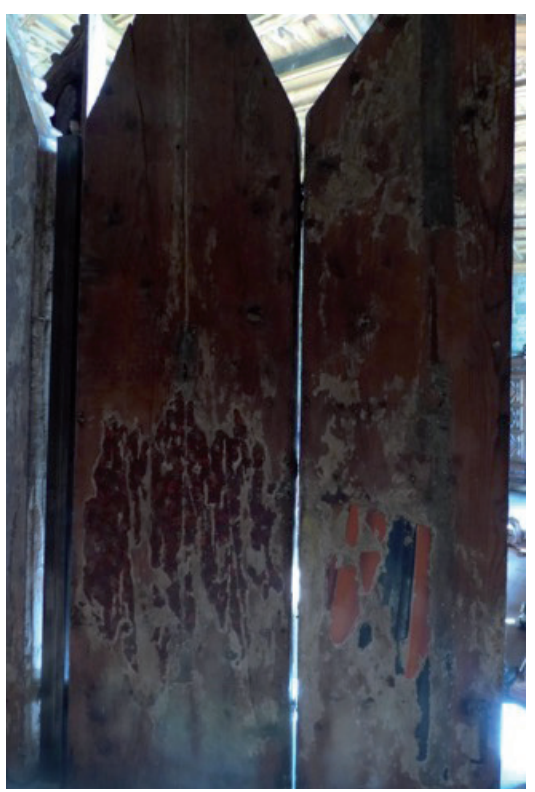




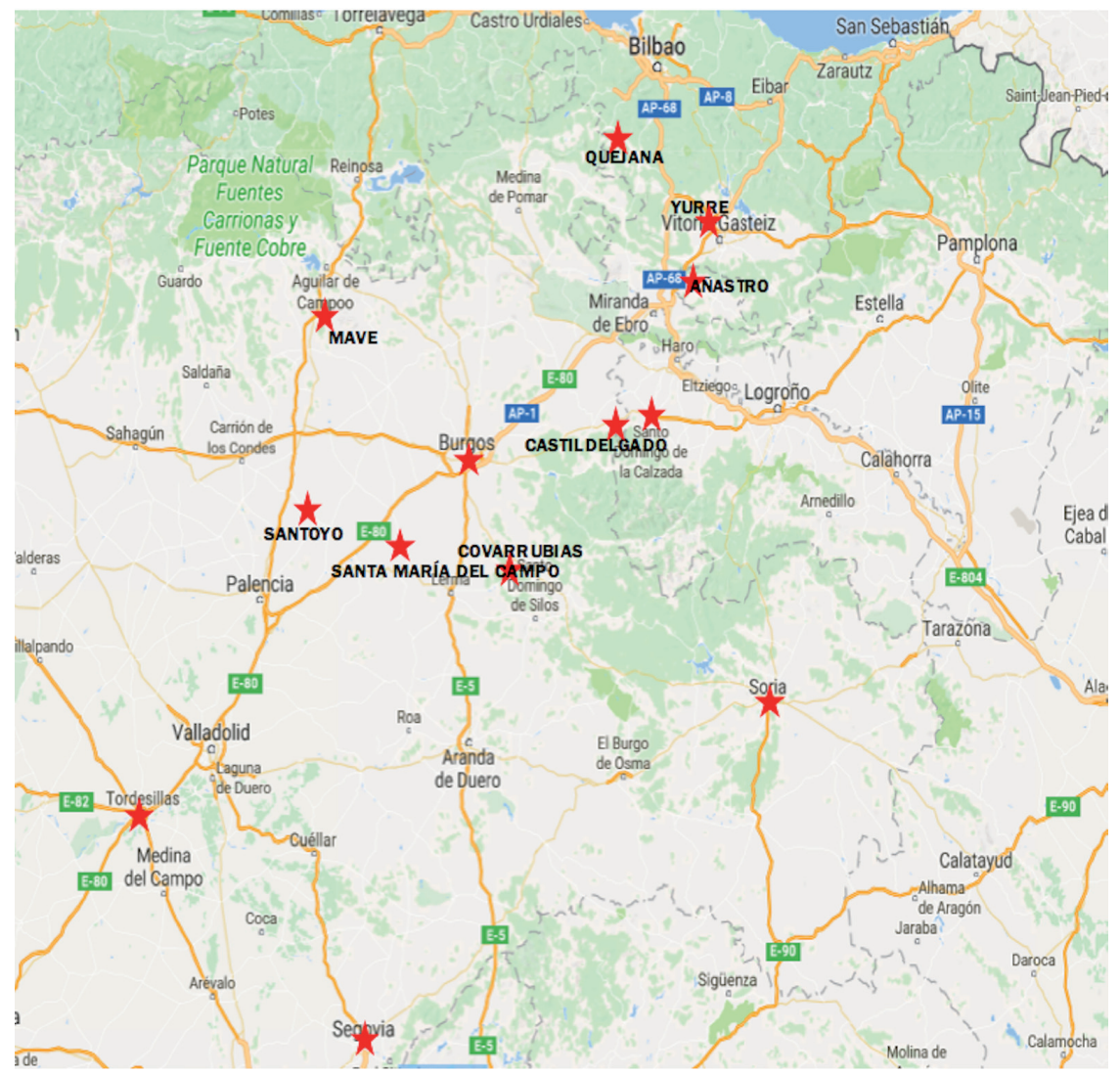

Fig. 8. Map of northern Castile, with original locations of panels marked with red stars. Image: author. 


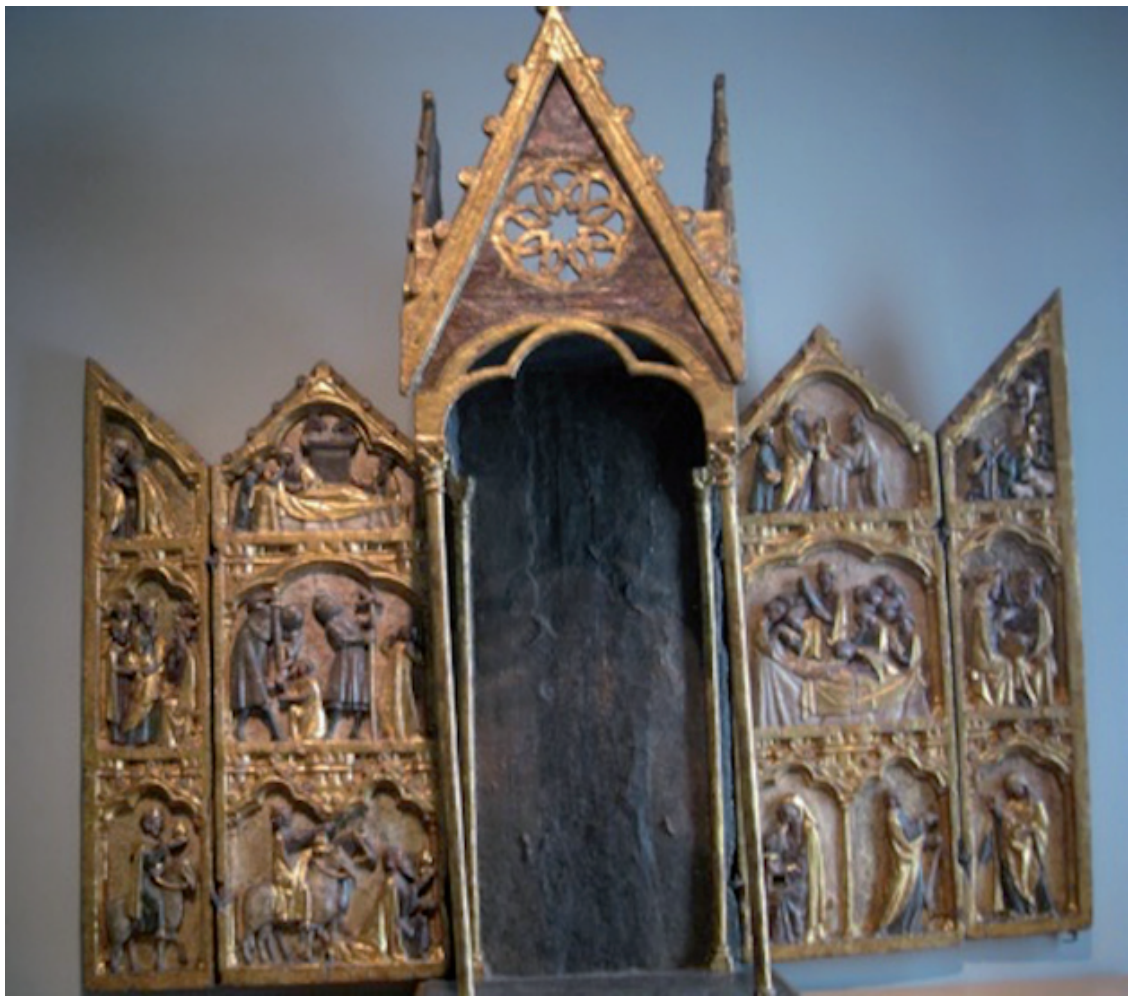

Fig. 9.

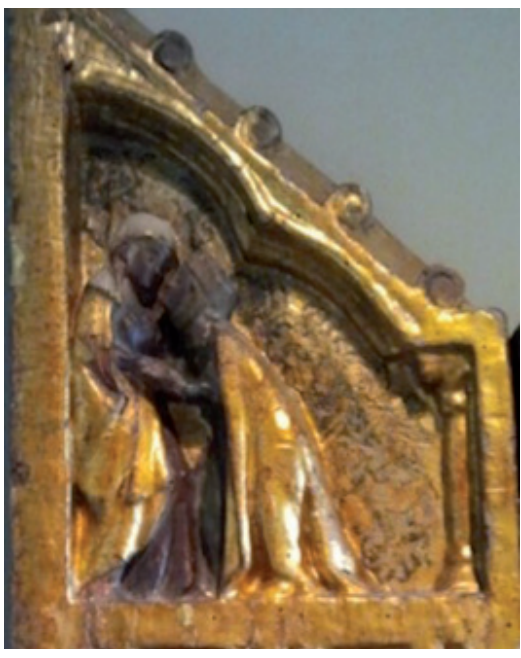

Closable polyptych from Castildelgado, ca I300. Polychrome wood, $203 \times 222 \times 64 \mathrm{~cm}$. Frederic Marès Musum, Barcelona. Photo: author.

Fig. Io.

Detail of the Visitation,

Castildelgado Polyptych. Photo: author. 


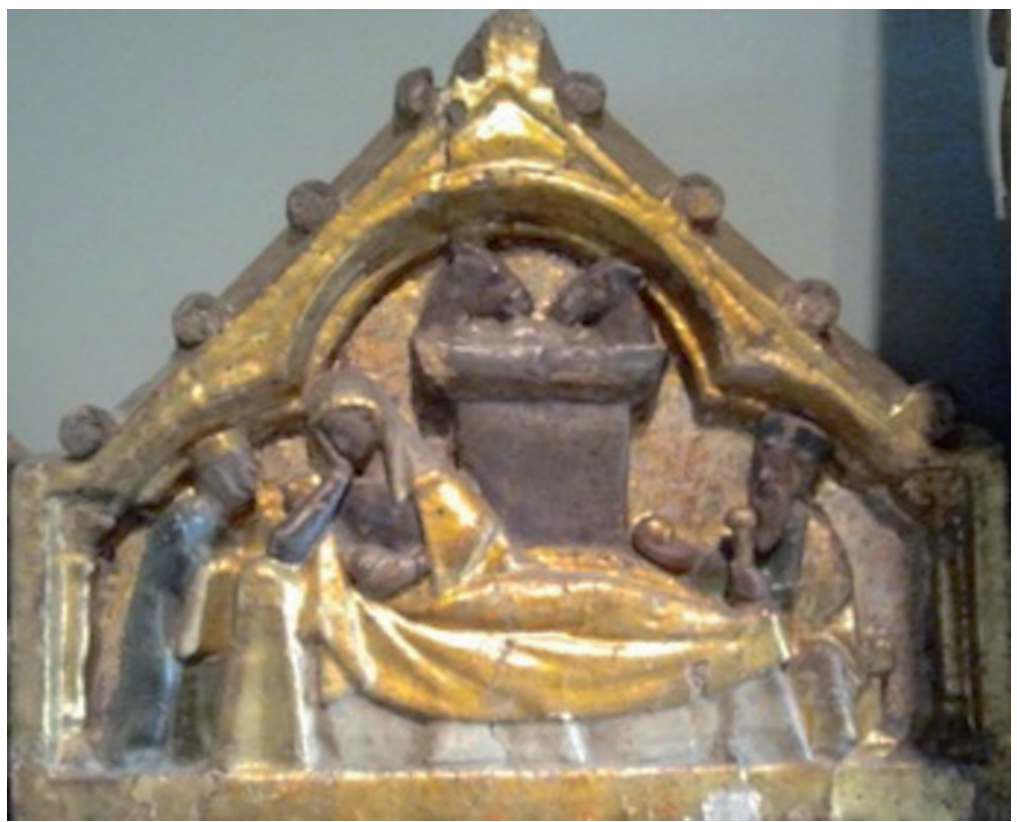

Fig. II. Detail of the Nativity, Castildelgado Polyptych. Photo: author.

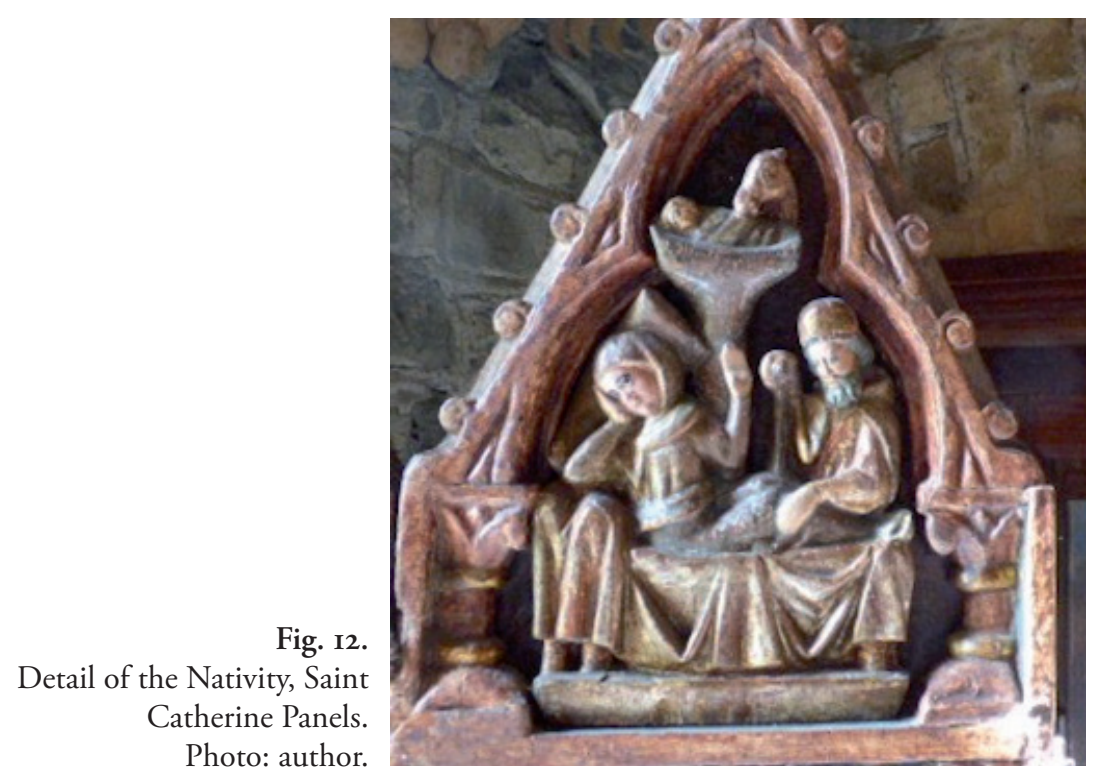




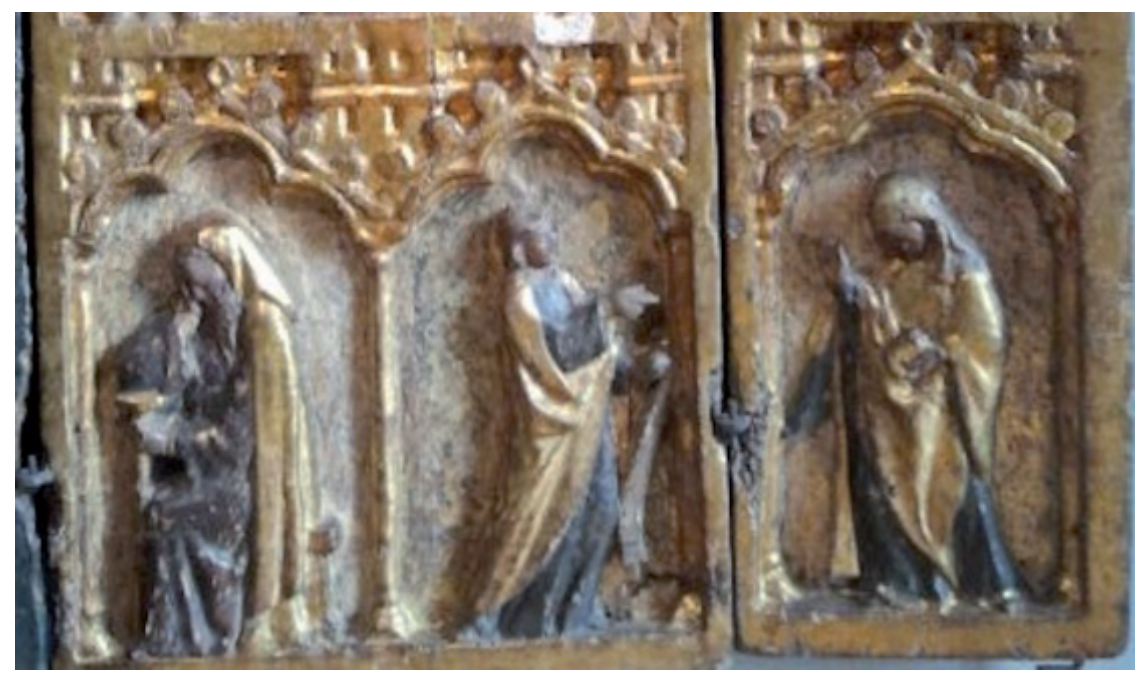

Fig. I3. Detail of Saint Joseph and the Annunciation in the Castildelgado Polyptych. Photo: author.
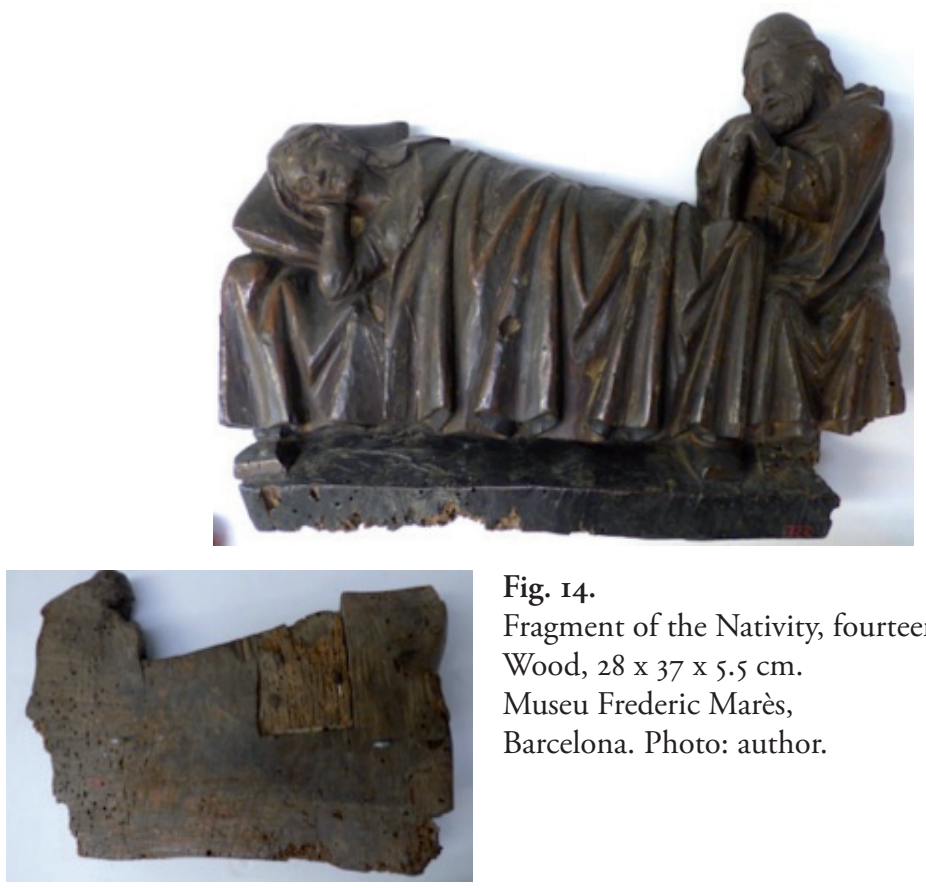

Fig. I4.

Fragment of the Nativity, fourteenth century. Wood, $28 \times 37 \times 5.5 \mathrm{~cm}$. Museu Frederic Marès, Barcelona. Photo: author. 


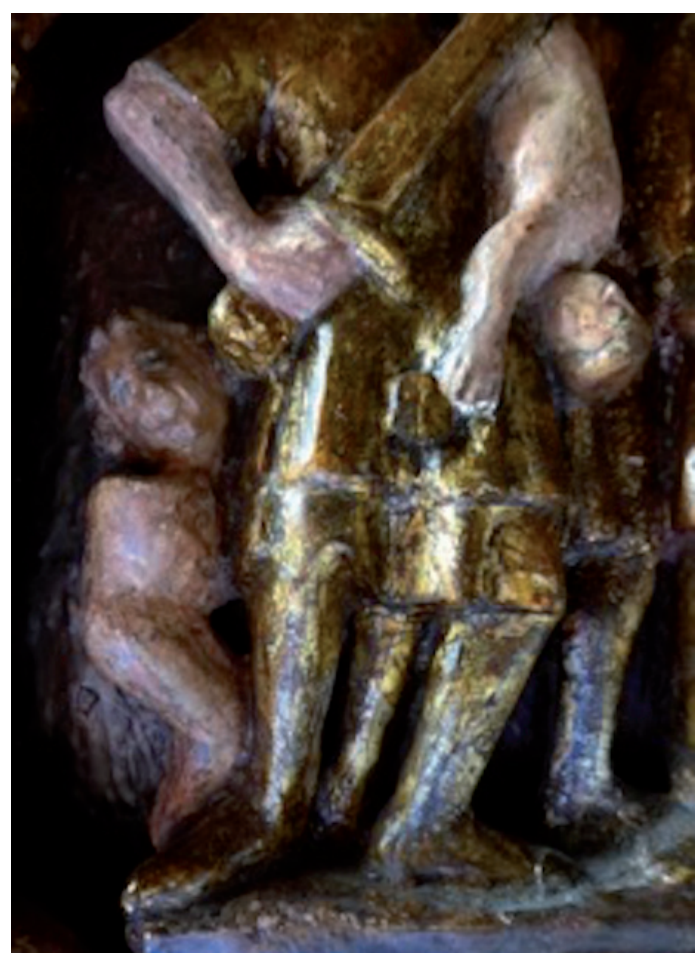

Fig. 15 . Crouching infant in the Massacre of the Innocents, Saint Catherine Polyptych. Photo: author.

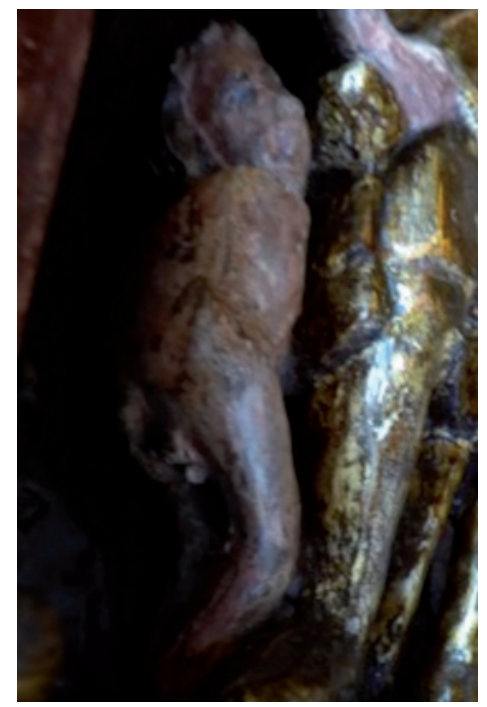




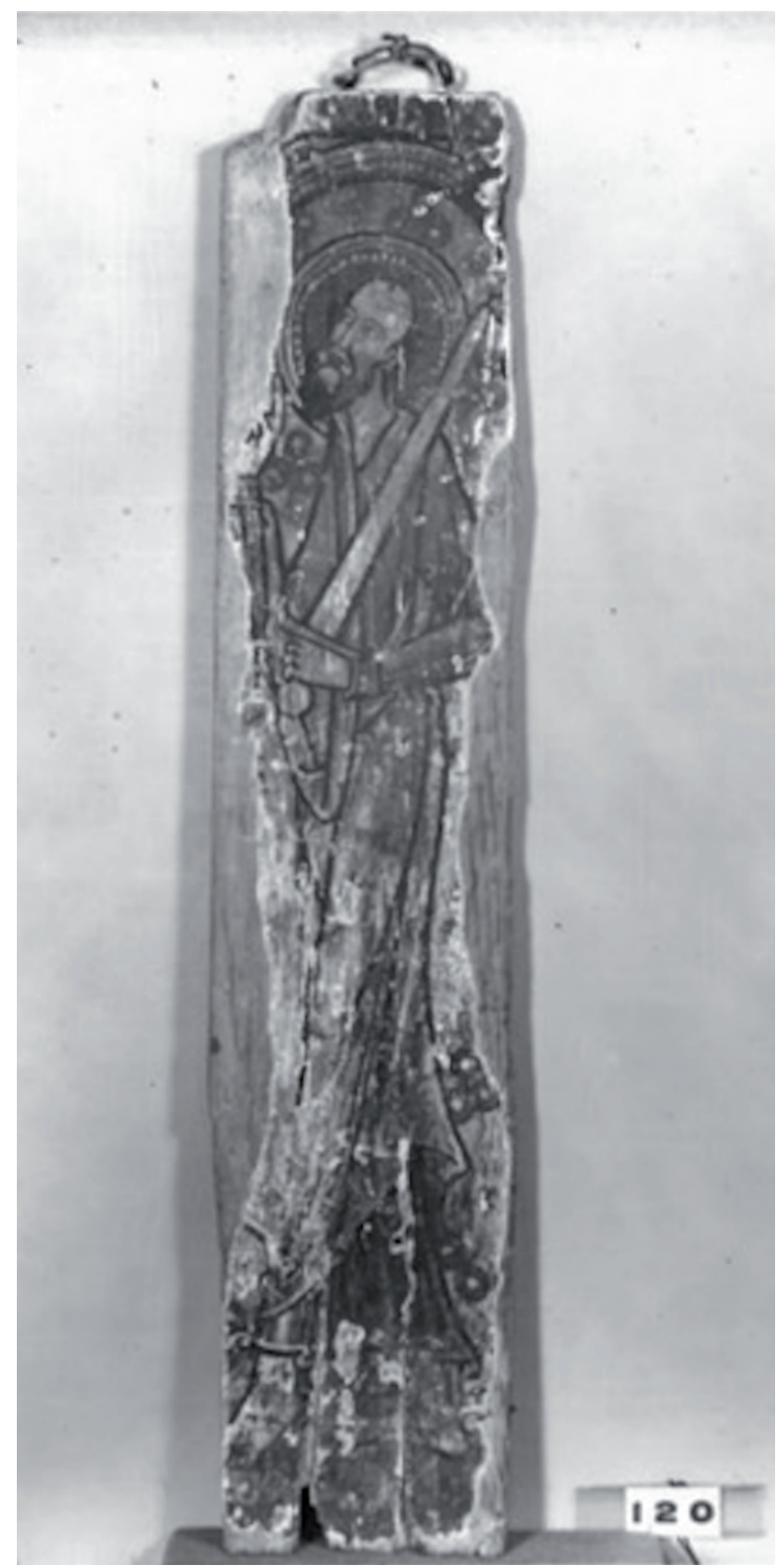

Fig. I6. Panel displaying painted figure of Saint Paul, Ávila. Photo: Fundació Institut Amatller d'Art Hispànic, Arxiu Mas. 


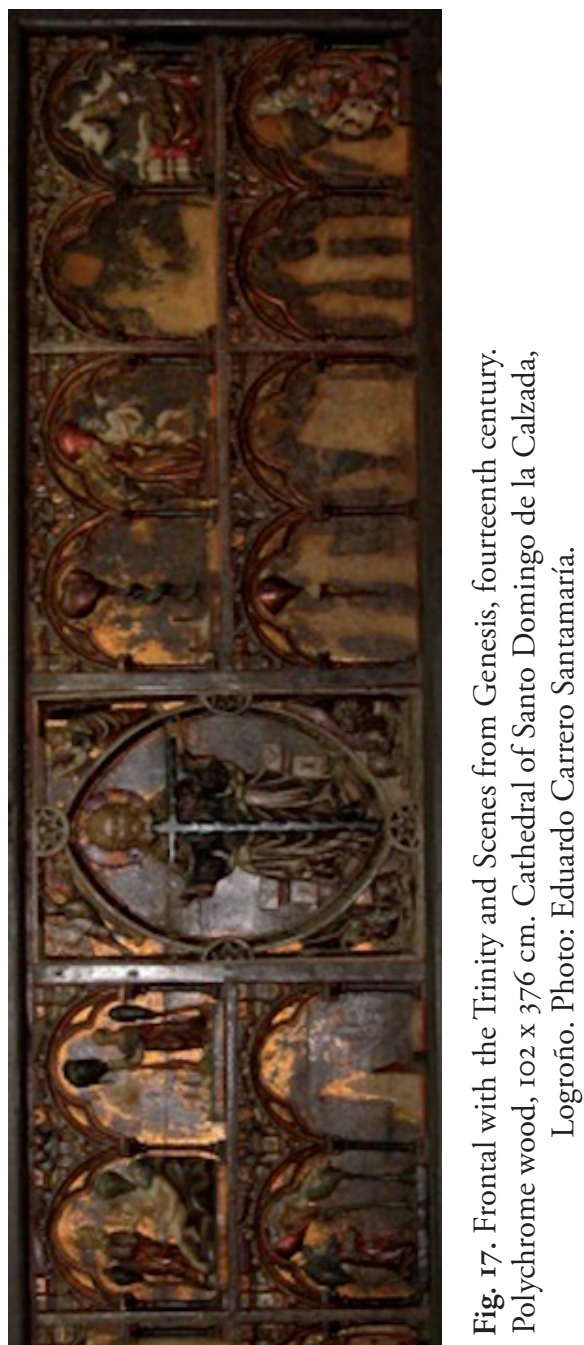



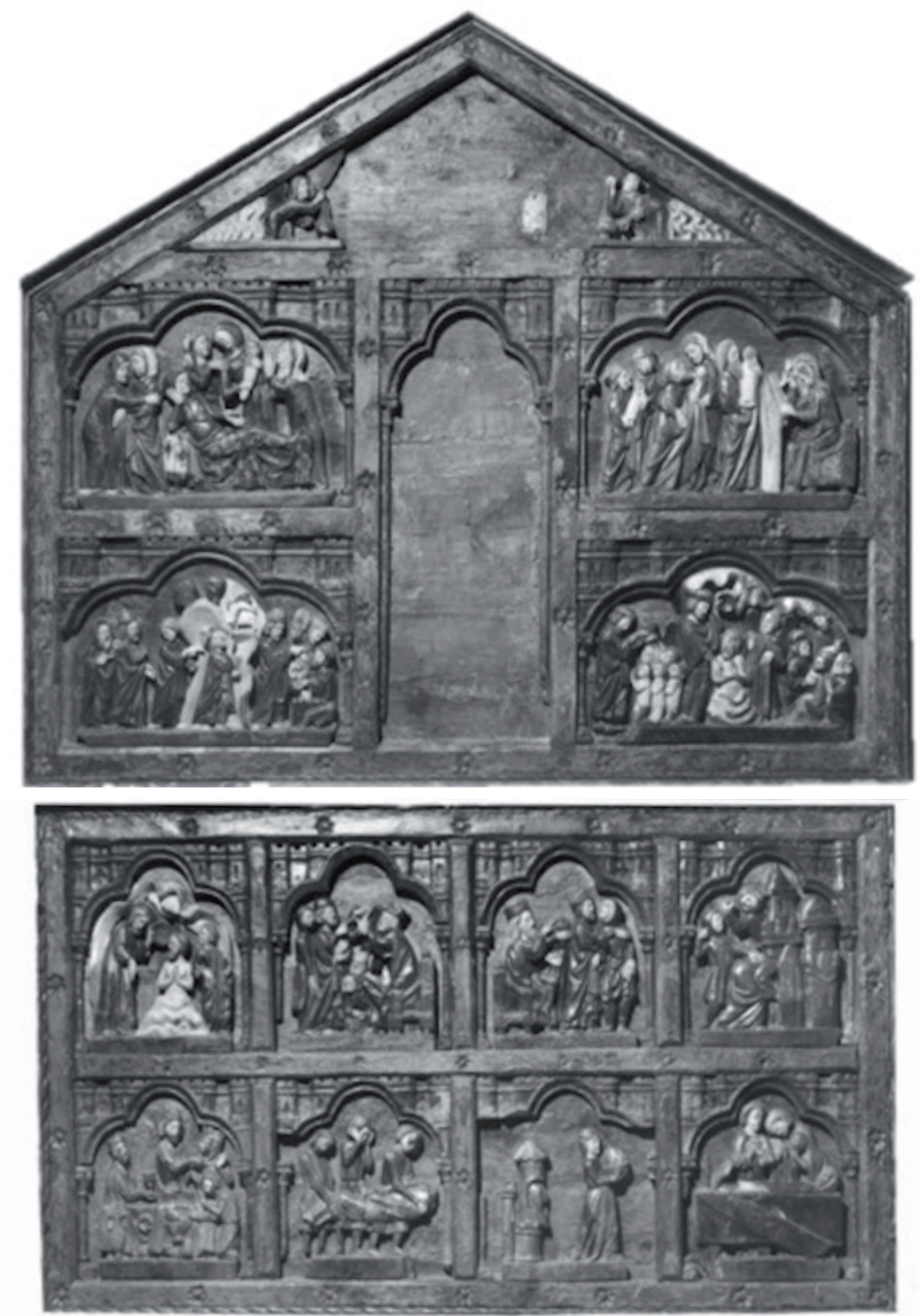

Fig. I8. Altarpiece and frontal ensemble with the life of Saint John the Baptist, late thirteenth-century.

Polychrome wood, I48.5 x I98.2 cm (altarpiece) and IO2 x I92 (frontal).

Prado Museum, Madrid. Photo: Fundació Institut Amatller d'Art Hispànic, Arxiu Mas. 


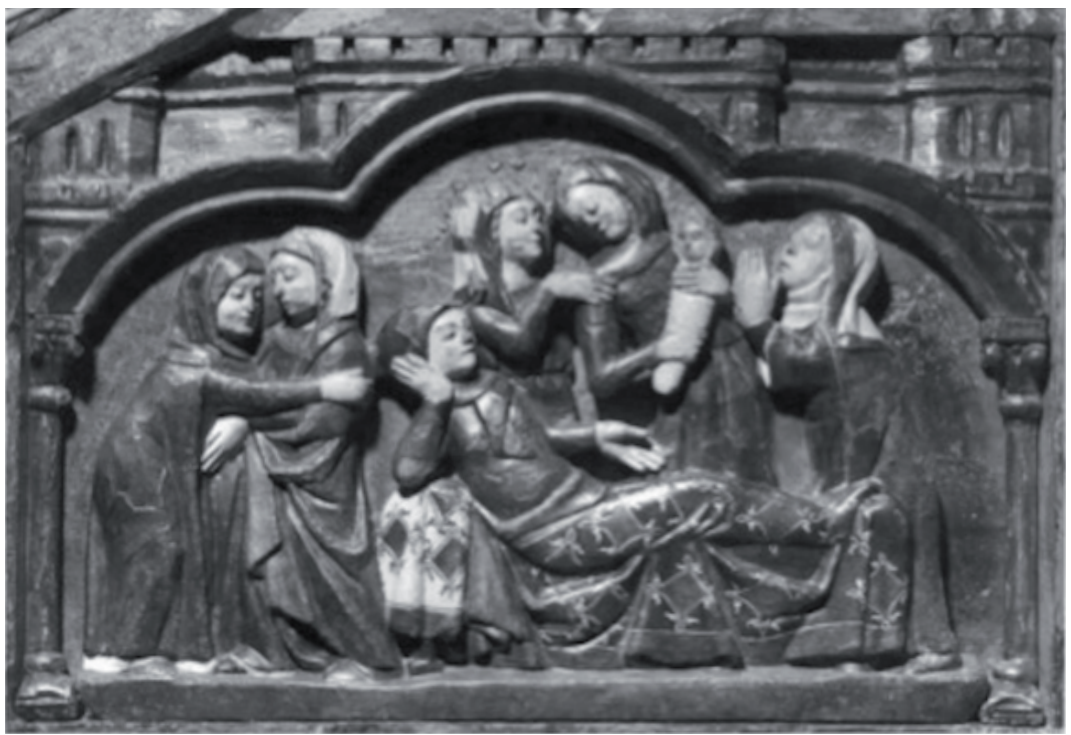

Fig. 19. Saint Elizabeth on her bed, Saint John the Baptist panels, Prado. Photo: Fundació Institut Amatller d'Art Hispànic, Arxiu Mas.

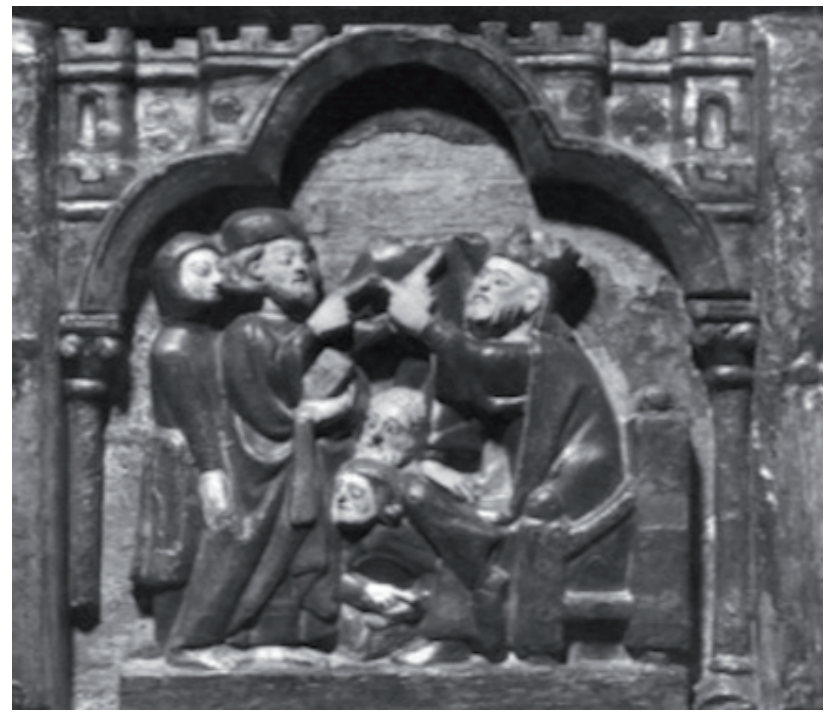

Fig. 20. Detail of King Herod, Saint Joseph the Baptist panels, Prado. Photo: Fundació Institut Amatller d'Art Hispànic, Arxiu Mas. 


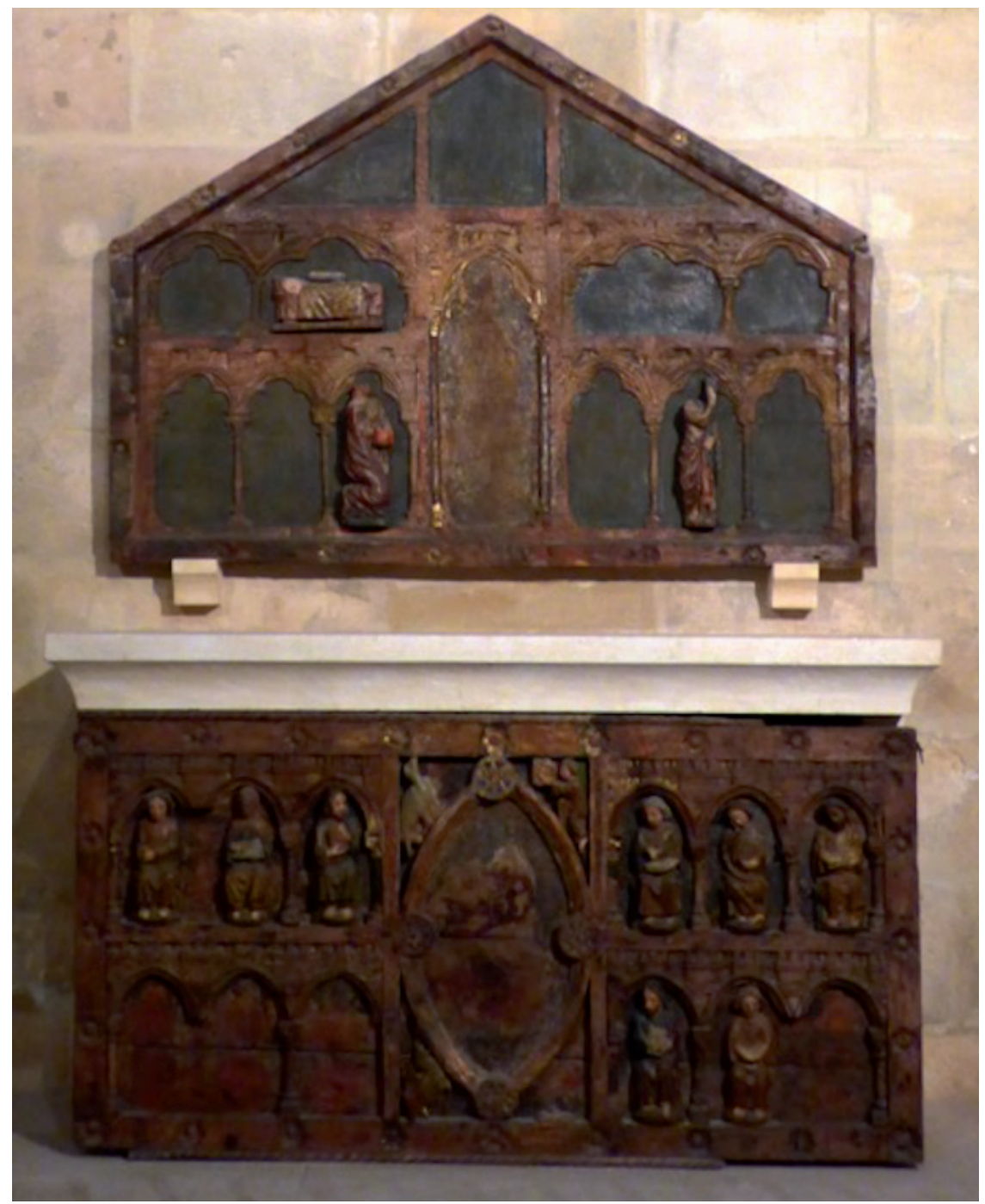

Fig. 2I. Altarpiece and frontal ensemble from the church of Santa Maria, Mave, thirteenth-century. Polychrome wood, I52 X I99.5 cm (altarpiece) and IO4 X I99.5 cm (frontal). Saint Nicolas chapel, Burgos cathedral. Photo: author. 


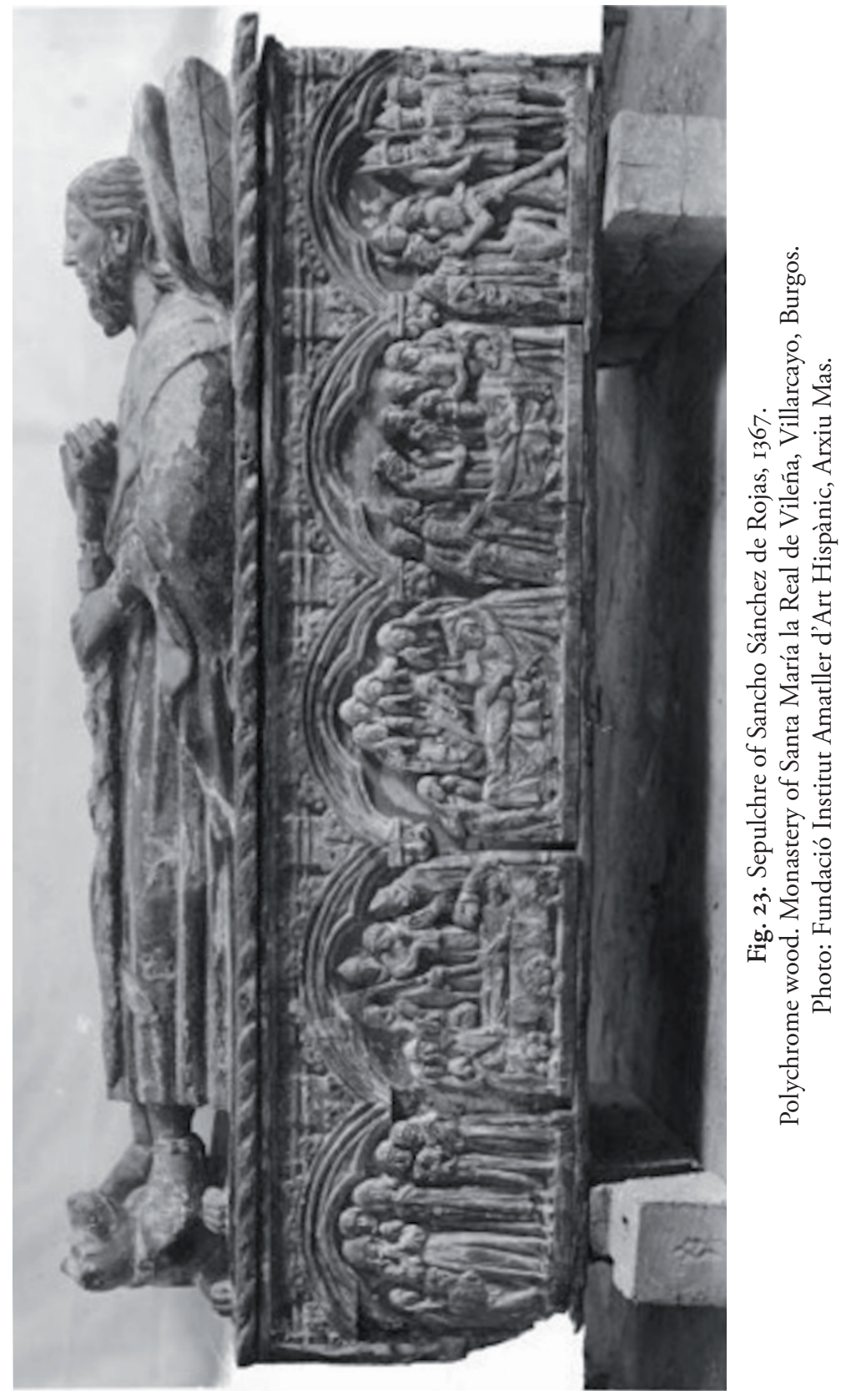




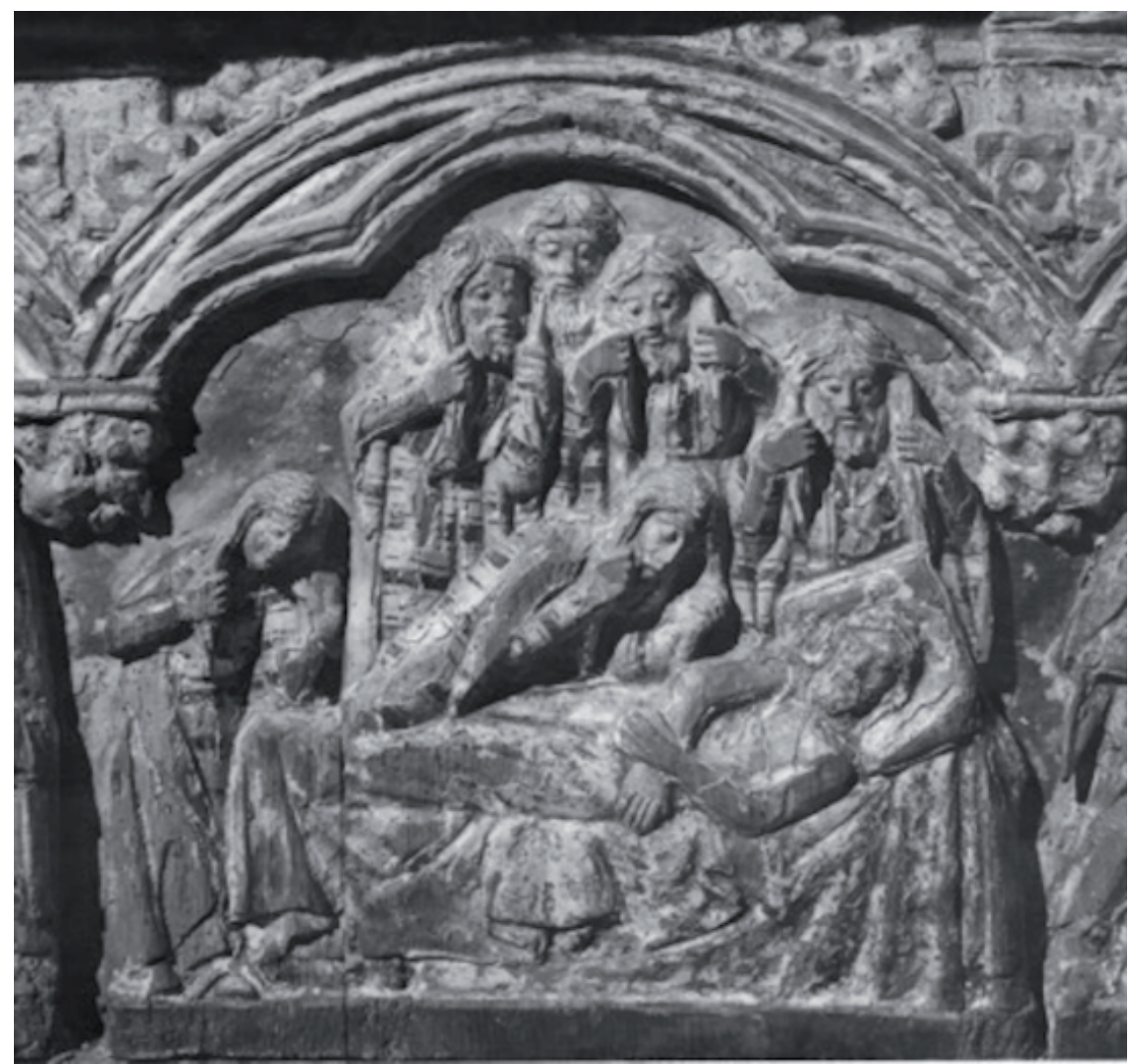

Fig. 24. Detail of grieving figures on the sepulchre of Sancho Sánchez de Rojas, 1367. Monastery of Santa María la Real de Vileńa, Villarcayo, Burgos. Photo: Fundació Institut Amatller d'Art Hispànic, Arxiu Mas. 


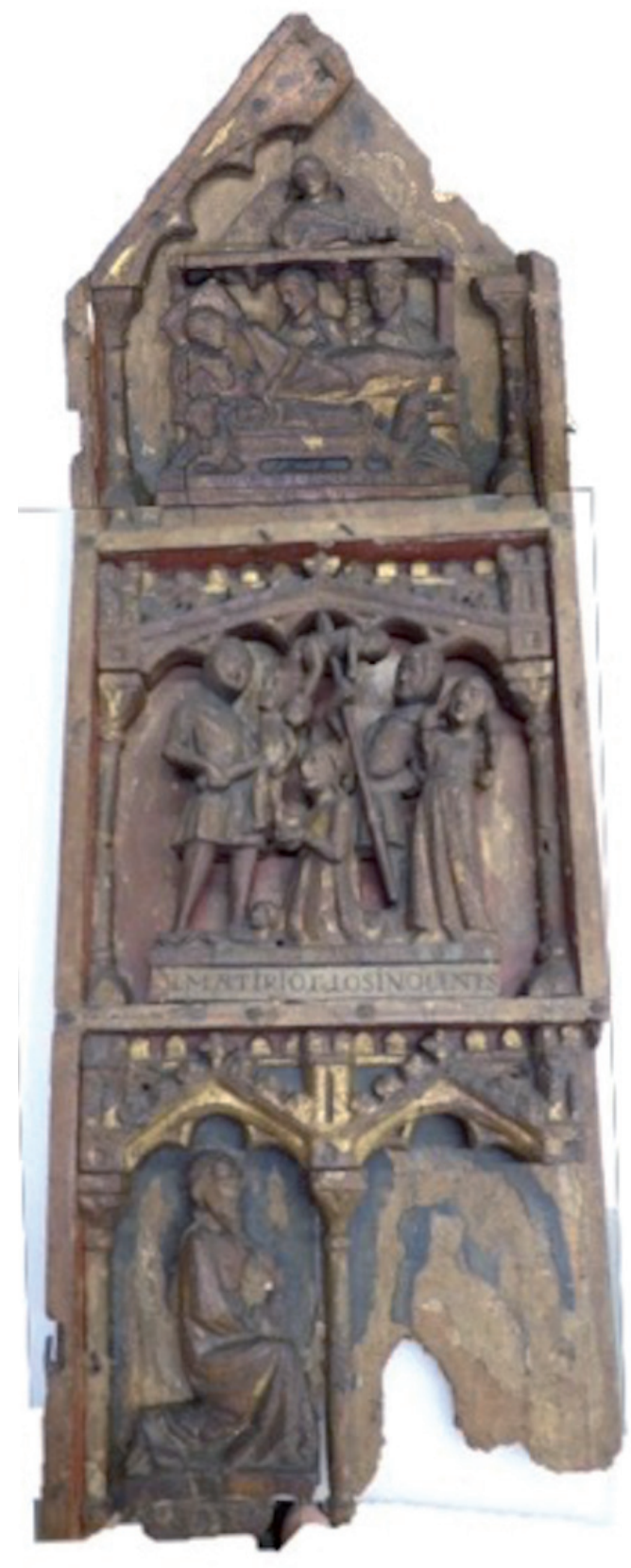

Fig. 25 .

Fragment of a polyptych with the Massacred of the Innocents, after 1300 .

Polychrome wood. 144 x $45 \times 5 \mathrm{~cm}$. Museu Frederic Marès, Barcelona. Photo: Author. 